\title{
Influence of Compost from Post-Consumer Wood on Development, Nutrition State of Plants, Microbiological and Biochemical Parameters of Substrates in Zonal Pelargonium (Pelargonium zonale)
}

\author{
Anita Schroeter-Zakrzewska ${ }^{1, *}$, Agnieszka Wolna-Maruwka ${ }^{2}$, Tomasz Kleiber ${ }^{3}$ (D), Hanna Wróblewska 4 \\ and Katarzyna Głuchowska ${ }^{2}$ \\ check for \\ updates \\ 1 Department of Ornamental Plants, Dendrology and Pomology, Poznan University of Life Sciences, \\ Dąbrowskiego 159, 60-594 Poznań, Poland \\ 2 Department of General and Environmental Microbiology, Poznan University of Life Sciences, Szydłowska 50, \\ 60-656 Poznań, Poland; agnieszka.wolna-maruwka@up.poznan.pl (A.W.-M.); \\ kasia.gluchowska@up.poznan.pl (K.G.) \\ 3 Department of Plant Nutrition, Poznan University of Life Sciences, Zgorzelecka 4, 60-198 Poznań, Poland; \\ tomasz.kleiber@up.poznan.pl \\ 4 Environmental Protection and Wood Chemistry Laboratory, Łukasiewicz Research Network-Wood \\ Technology Institute, Winiarska 1,60-654 Poznań, Poland; h_wroblewska@itd.poznan.pl \\ * Correspondence: anita.schroeter-zakrzewska@up.poznan.pl
}

Citation: Schroeter-Zakrzewska, A.; Wolna-Maruwka, A.; Kleiber, T.; Wróblewska, H.; Głuchowska, K. Influence of Compost from Post-Consumer Wood on Development, Nutrition State of Plants, Microbiological and Biochemical Parameters of Substrates in Zonal Pelargonium (Pelargonium zonale). Agronomy 2021, 11, 994. https://doi.org/10.3390/ agronomy11050994

Academic Editor: Domenico Ronga

Received: 15 April 2021

Accepted: 14 May 2021

Published: 17 May 2021

Publisher's Note: MDPI stays neutral with regard to jurisdictional claims in published maps and institutional affiliations.

Copyright: (c) 2021 by the authors. Licensee MDPI, Basel, Switzerland. This article is an open access article distributed under the terms and conditions of the Creative Commons Attribution (CC BY) license (https:/ / creativecommons.org/licenses/by/ $4.0 /)$.
Abstract: The purpose of this study was to assess the possibility of using compost made from postconsumer wood in zonal pelargonium (Pelargonium zonale) cv. 'Tex Mex' cultivation. The influence of compost on the plant's development and nutritional state, as well as the microbiological and enzymatic activity of the substrate was examined. Two variants of compost marked with the following letters: OPA and OPB were used. Both variants consisted of post-consumer wood waste (OP) (70\% of weight) mixed with powdery waste from processing MDF boards $(6 \%)$, mature compost from fiberboard waste (19\%), high peat (4\%), water and a biological inoculum "Activit Las". Thirty kilograms of urea in two portions per prism were added to the OPA variant while ammonium nitrate (1.5 $\mathrm{kg}$ per prism), magnesium sulphate $(0.4 \mathrm{~kg}$ per prism), potassium phosphate $(0.8 \mathrm{~kg}$ per prism) and calcium phosphate $(0.9 \mathrm{~kg}$ per prism) were added to the OPB variant. The plants were cultivated into pots $12 \mathrm{~cm}$ in diameter and a capacity of $659 \mathrm{dm}^{3}$ in the substrates consisting of peat with the addition of compost at different volume ratios. It was found that the medium type had a significant influence on the growth and flowering of the zonal pelargonium. The type of compost used was the determinant for microbiological total counts and activity. The chemical composition of the substrates significantly modified the plants' nutritional state in terms of macro- and microelements. In summary, the study demonstrated that good quality ornamental plants can be successfully grown in peat substrate containing $25 \%$ or $50 \%$ of post-consumer wood compost.

Keywords: post-consumer wood; nutrition; enzymatic activity; zonal pelargonium

\section{Introduction}

The rational use of natural resources and proper waste management are the most significant principles of sustainable development.

Reducing the use of raw materials is the most effective environmental approach to solving the waste problem. However, this requires reducing the extraction and consumption of materials, challenging existing production and consumption patterns [1].

Replacing natural raw materials such as peat in plant cultivation by compost made from organic waste can be considered as a practical application of these principles. Due to the excessive and long-term exploitation, high peat deposits are shrinking and their prices 
are constantly growing. Nowadays, only about $20 \%$ of the growing media used in European Union comprise materials other than peat [2]. During the last 20 years, peat extraction has come under increasing scrutiny throughout Europe and particularly in the UK [3]. This forces plant manufacturers to seek substitutes. Organic materials like coconut, wood fiber, compost, etc., could be used as substitutes.

On the other hand, the development of civilization leads to significant increases in waste of different origins that should be managed in a way that ensures the protection of human life and health as well as the protection of the environment. Waste management cannot, in any case, pose threats to the water, air, soil, plants and animals. As a result of this, an increase is being observed in the recovery of waste coming from different economic sectors, including agriculture, industry and also urban waste, coming mostly from households [4]. A significant amount of this waste constitutes organic waste which, because of its biodegradability, cannot be deposited on waste landfill sites.

One of the organic waste utilization methods is composting. The composting of organic waste is the most common technology of recycling and disposing of them easily in a safe way [5]. Composting should be understood as the recovery of waste and, more precisely as organic recycling. The definition of organic recycling states that it is oxygen (aerobic) treatment, including composting, or oxygen-free processing of waste that is biologically degraded in the controlled conditions by bacteria, as a result of which organic matter or methane is produced; disposal on a waste landfill is not regarded as organic recycling. Research into the influence of compost made from (among others) timber industry waste (bark, wood chips, sawdust), sewage sludge or urban waste and industrial waste on plant growth has been conducted by numerous researchers [6-11]. In addition, works on compost preparation from post-consumer waste wood (worn-out furniture, construction timber or building constructions) have been conducted. According to the principle of cascade recycling, composting as waste material utilization has a priority over the recovery of energy (thermal conversion). McMahon et al. [12] presented the issue of wood waste composting and also pointed to its positive impact on waste management.

Post-consumer wood reclaimed from old furniture, doors, windows, floors, construction materials and other wooden products that have ended their life cycle consists of $90 \%$ of a cellulose-lignin complex and $10 \%$ of finishing materials permanently bonded with wood. These finishing materials are mostly comprised of resins, adhesives, varnishes, foils, laminates and preservatives used in the production process of composite wood products (particle boards, fibre boards, plywood). Composite wood products have been replacing solid wood in the production of furniture, doors, windows, floors and even wood constructions. Due to the high content of lignin in wood, its biodegradability occurs most easily under aerobic conditions, which means during the composting process.

Compost consisting of production and post-consumer wood waste are characterized by a relatively low $\mathrm{pH}$, high content of nitrogen compounds coming from urea formaldehyde (UF) resins, low content of remaining macroelements and high salinity. Compost density is comparable to peat density. In the recently conducted vegetative tests with lettuce and basil, it was stated that post-consumer wood compost can be used as additives to gardening substrates [13]. The usage of such compost is especially justified in ornamental plant cultivation. Due to the lack of sufficient information on ornamental plants reactions towards the substrates containing compost made from post-consumer wood in the literature, it is essential to perform preliminary vegetative tests on these compost applications for different plant species.

For many years, zonal pelargonium (Pelargonium zonale) is highly rated among balcony plants. Substrates based on high peat are mainly used in the cultivation process of this species. Due to the high costs of good quality peat and its diminishing deposits, substances that have similar properties, such as compost, are being sought for its replacement.

The purpose of the following study was to assess the possibility of using compost made from post-consumer wood in zonal pelargonium cultivation. Compost influence on 
the plant development and nutrition state as well as on microbiological and enzymatic activity of the substrate was examined.

\section{Materials and Methods}

\subsection{Plant Material and Growth Conditions}

The aim of this study was to test the possibility of the application of OPA or OPB compost as a substitute for peat in plant cultivation.

Composts from post-consumer wood were prepared in the Łukasiewicz Research Network-Wood Technology Institute in Poznań, Poland. Post-consumer wood came from the bulky waste landfill site of Waste Management Company in Poznań, Poland, and comprised old furniture, doors, windows, building constructions and partition walls. The waste consisted of the following materials: particle boards (raw, laminated, veneered, varnished), painted panels made of linen shives, soft and hard fibreboard (raw and varnished), MDF boards (veneered and laminated), block boards, plywood, cellular wood panels, and solid wood (raw and protected with different coatings).

The selected waste was preliminarily crushed in a Hammel crusher. Prior to further cutting, wood particles were separated from extraneous pollutants such as metals, glass, plastic and paper. Wood material subject to composting was grinded to a particle size less than $10 \mathrm{~mm}$. The process was conducted in open prisms of $\sim 5 \mathrm{~m}^{3}$. The prisms were formed on woven polyethylene mats placed directly on the ground. The outside protection was made from black non-woven fabric, which was water and air permeable. During the composting process, the temperature, moisture content and $\mathrm{pH}$ of the prisms were controlled. The prisms were aerated by means of supplying composted materials with the necessary oxygen for the development of aerobic microorganisms.

In order to maintain the optimum moisture (about $60 \%$ ), the prisms were sprinkled with tap water. During the 38 months of composting, the temperature in the OPA prism ranged from $2{ }^{\circ} \mathrm{C}$ to $55^{\circ} \mathrm{C}$, the humidity ranged from $50 \%$ to $70 \%$, and the $\mathrm{pH}$ value from 8.9 to 3.3. In the OPB prism, the temperature ranged from $3{ }^{\circ} \mathrm{C}$ to $56{ }^{\circ} \mathrm{C}$, moisture from $51 \%$ to $71 \%$ and $\mathrm{pH}$ value from 6.2 to 3.7. Two variants of compost (marked as $\mathrm{OPA}$ and $\mathrm{OPB}$ ) were prepared. Both variants consisted of post-consumer wood waste (OP) (70\% of its weight), mixed with powdery waste from processing MDF boards (6\%), mature compost made from fiberboard waste (19\%), high peat (4\%), water and a biological inoculum "Activit Las". "Activit Las" (produced by Atlas Planta S.C., Bydgoszcz, Poland) is biological inoculum containing selected bacteria, actinobacteria and fungi intended to accelerate the composting of lignocellulosic materials, including wood.

Thirty kilograms of urea in two portions per prism were added to the OPA variant while ammonium nitrate (1.5 kg per prism), magnesium sulphate $(0.4 \mathrm{~kg}$ per prism), potassium phosphate $(0.8 \mathrm{~kg}$ per prism) and calcium phosphate $(0.9 \mathrm{~kg}$ per prism) were added to the OPB variant.

The vegetation experiment was conducted in a heated greenhouse located at the Experimental Station of the Departments of the Faculty of Agronomy, Horticulture and Bioengineering (Department of Ornamental Plants, Dendrology and Pomology). The studies were conducted in cultivation on zonal pelargonium (Pelargonium zonale) cv.'Tex Mex' as a model plant. Rooted cuttings were planted into pots of $\left(12 \mathrm{~cm}\right.$ diameter, V $\left.659 \mathrm{~cm}^{3}\right)$.

The plants were cultivated in substrates consisting of peat with addition the $r$ OPB compost in different volume ratios. The particular combinations of substrate are shown in Table 1. 
Table 1. The combinations of substrate.

\begin{tabular}{ccc}
\hline Substrate Treatments & Compost OPA or OPB & Peat \\
\hline I & $100 \%$ & - \\
II & $75 \%$ & $25 \%$ \\
III & $50 \%$ & $50 \%$ \\
IV & $25 \%$ & $75 \%$ \\
Control & - & $100 \%$ \\
\hline
\end{tabular}

The experiment comprised nine combinations (OPA I, OPA II, OPA III, OPA IV, OPB I, OPB II, OPB III, OPB IV and Control) each of which consisted of 15 replications, where one plant was one replication. The control group consisted of plants grown in high peat substrate. The chemical composition of the substrate used for the experiment before and after plant cultivation is shown in Table 2.

Table 2. The chemical composition of the medium used at the beginning and after the end of the experiment.

\begin{tabular}{|c|c|c|c|c|c|c|c|c|c|c|c|c|}
\hline \multirow{2}{*}{ Medium } & $\mathrm{N}-\mathrm{NO}_{3-}$ & $\mathbf{P}$ & $\mathbf{K}$ & $\mathrm{Ca}$ & Mg & $\mathbf{F e}$ & Mn & Zn & $\mathrm{Cu}$ & $\mathrm{Cl}$ & \multirow{2}{*}{$\begin{array}{c}\text { Salinity g } \\
\mathrm{NaCl}\end{array}$} & \multirow{2}{*}{$\mathrm{pH}$} \\
\hline & \multicolumn{10}{|c|}{$\mathrm{mg} \cdot \mathrm{dm}^{-3}$} & & \\
\hline \multicolumn{13}{|c|}{ Beginning of the experiment } \\
\hline Control-peat & 8 & 57 & 35 & 2581 & 139 & 43.5 & 5.78 & 3.74 & 0.38 & 72 & 1.33 & 6.3 \\
\hline \multicolumn{13}{|c|}{ End of the experiment } \\
\hline Control-peat & 20 & 40 & 10 & 2624 & 210 & 21.8 & 4.16 & 5.88 & 1.28 & 349 & 1.99 & 6.7 \\
\hline \multicolumn{13}{|c|}{ OPA beginning of the experiment } \\
\hline $100 \%$ compost & 546 & 29 & 55 & 570 & 47 & 45.0 & 17.68 & 720.0 & 1.58 & 37 & 2.97 & 3.6 \\
\hline $75 \%$ compost $+25 \%$ peat & 357 & 29 & 45 & 974 & 67 & 56.5 & 14.70 & 539.5 & 0.94 & 46 & 2.05 & 5.0 \\
\hline $50 \%$ compost $+50 \%$ peat & 320 & 25 & 40 & 1296 & 87 & 51.2 & 13.26 & 411.5 & 0.78 & 55 & 2.07 & 5.4 \\
\hline $25 \%$ compost $+75 \%$ peat & 167 & 29 & 40 & 1887 & 117 & 6.0 & 9.94 & 203.6 & 0.42 & 67 & 1.85 & 6.2 \\
\hline \multicolumn{13}{|c|}{ OPA end of the experiment } \\
\hline $100 \%$ compost & 300 & 37 & 78 & 697 & 99 & 43.6 & 13.02 & 635.0 & 2.64 & 250 & 2.46 & 4.2 \\
\hline $75 \%$ compost $+25 \%$ peat & 249 & 23 & 60 & 989 & 108 & 38.9 & 11.32 & 607.0 & 3.78 & 227 & 2.25 & 4.9 \\
\hline $50 \%$ compost $+50 \%$ peat & 317 & 37 & 50 & 1595 & 174 & 31.7 & 4.54 & 393.0 & 1.94 & 372 & 3.03 & 5.8 \\
\hline $25 \%$ compost $+75 \%$ peat & 211 & 30 & 30 & 1948 & 196 & 24.7 & 1.52 & 195.8 & 1.68 & 411 & 2.75 & 6.0 \\
\hline \multicolumn{13}{|c|}{ OPB beginning of the experiment } \\
\hline $100 \%$ compost & 733 & 50 & 70 & 591 & 53 & 57.4 & 19.40 & 786.0 & 0.90 & 39 & 4.30 & 3.7 \\
\hline $75 \%$ compost $+25 \%$ peat & 460 & 36 & 55 & 974 & 70 & 54.5 & 15.26 & 594.5 & 0.48 & 49 & 2.46 & 5.2 \\
\hline $50 \%$ compost $+50 \%$ peat & 408 & 36 & 50 & 1183 & 104 & 44.8 & 12.80 & 379.5 & 0.44 & 66 & 2.76 & 5.8 \\
\hline $25 \%$ compost $+75 \%$ peat & 251 & 36 & 45 & 1845 & 119 & 41.9 & 10.80 & 244.0 & 0.42 & 69 & 2.28 & 6.2 \\
\hline \multicolumn{13}{|c|}{ OPB end of the experiment } \\
\hline $100 \%$ compost & 215 & 30 & 55 & 545 & 74 & 48.7 & 10.36 & 541.0 & 1.54 & 169 & 1.84 & 4.2 \\
\hline $75 \%$ compost $+25 \%$ peat & 298 & 27 & 55 & 919 & 109 & 46.5 & 9.22 & 509.0 & 1.34 & 238 & 2.45 & 4.7 \\
\hline $50 \%$ compost $+50 \%$ peat & 355 & 30 & 50 & 1635 & 154 & 34.9 & 5.00 & 391.0 & 1.44 & 297 & 3.00 & 5.5 \\
\hline $25 \%$ compost $+75 \%$ peat & 131 & 30 & 10 & 2039 & 179 & 33.9 & 1.80 & 228.2 & 1.06 & 266 & 2.48 & 6.1 \\
\hline
\end{tabular}

\subsection{Morphological Features}

The measurements of the following characteristics were taken during the experiment: the leaf level, the number of leaves, the length of the inflorescence, the number of the inflorescences. The fresh and dry matter of the leaves, as well as the inflorescence of the fresh and dry matter, were determined. The index of the leaves' greenness SPAD was determined by means of Yara N-Tester apparatus. For each plant, the index of leaves greenness SPAD measurement was made on three leaves. The mean sample consisted of 45 leaves per one treatment. This measurement is used to determine the intensity of the leaves' green colour and is calculated as a quotient of light absorption connected with chlorophyll presence at the wavelength of $650 \mathrm{~nm}$ and the absorption by the leaf tissue at 
the wavelength of $940 \mathrm{~nm}$ [14]. The size of the leaf assimilation area was measured as well by means of CL-202 Portable Leaf Area Meter.

The plants at the beginning (term I) and at the end (term II) of the vegetative tests as well as representative substrate samples were taken for microbiological, enzymatic and chemical analyses.

\subsection{Microbiome Determination}

The scope of the experiments comprised the determination (in five replications) of the total count of bacteria, actinobacteria and fungi. The groups of microorganisms were cultured according to the plate method on solid substrates using appropriate dilutions of compost/peat solutions, expressed as CFU. $\mathrm{g}^{-1}$ of compost/peat dry matter. The counts of heterotrophic bacteria were determined on Merck standard agar medium following 5-6-days of incubation at a temperature of $28^{\circ} \mathrm{C}$ [15]. Numbers of actinobacteria were determined on Pochon selective medium with a starch addition [16] on incubating plates for 7 days at a temperature of $26^{\circ} \mathrm{C}$. The count of mold was determined on a medium with Rose Bengal Agar and aureomycin added [17]. Plates were incubated for 6 days at a temperature of $25^{\circ} \mathrm{C}$.

\subsection{Enzymatic Activity Determination}

Biochemical analysis were performed on the basis the spectrophotometric method (all measurements were performed in five replications). Dehydrogenase (EC 1.1.1.) activity (DHA) was determined according to Thalmann [18] with some minor modifications. Compost/peat $(1 \mathrm{~g})$ was incubated for $24 \mathrm{~h}$ with 2, 3, 5-triphenyltetrazolium chloride (TTC) at $30{ }^{\circ} \mathrm{C}, \mathrm{pH}$ 7.4. The produced triphenylformazan (TPF) was extracted with $96 \%$ ethanol and measured spectophotometrically at $485 \mathrm{~nm}$. Dehydrogenase activity was expressed as $\mu \mathrm{mol} \mathrm{TPF} \mathrm{g}^{-1} \mathrm{DM}$ of compost/peat $24 \mathrm{~h}^{-1}$.

The activity of acid (EC 3.1.3.2) phosphomonoesterases (PAC) acid was assayed as described by Tabatabai and Bremner [19]. Briefly, $1 \mathrm{~g}$ of moist compost/peat was incubated with $0.25 \mathrm{~mL}$ of toluene for $15 \mathrm{~min}$ at room temperature. Next, $5 \mathrm{~mL}$ of the buffer solution was added to the compost/peat samples. The $\mathrm{pH}$ of the buffer solution was 6.5 , and it contained p-nitrophenylophosphate sodium substrate, which was solved in it. After the incubation $1 \mathrm{~mL}$ of $0.5 \mathrm{M} \mathrm{CaCl}_{2}$ and $4 \mathrm{~mL}$ of $0.5 \mathrm{M} \mathrm{NaOH}$ were added to all the test tubes in order to stop the reaction. Next, the solution was drained through paper filters Munktell Ahlstrom firm $(90 \mathrm{~mm})$ and the value was read on a spectrophotometer at a wavelength of $400 \mathrm{~nm}$. The enzyme activity was expressed as $\mu \mathrm{mol} \mathrm{PNP} \mathrm{g}{ }^{-1} \mathrm{DM}$ of compost $/ \mathrm{peat}^{-1}$.

Soil urease (EC 3.5.1.5) activity (URE) was assayed as described by Hoffmann et al. [20]. Briefly, $1 \mathrm{~g}$ of moist compost/peat was incubated with $0.15 \mathrm{~mL}$ of toluene for $15 \mathrm{~min}$ at room temperature. Next, $1 \mathrm{~mL}$ of the urea solution was added to the compost/peat samples and incubated for $18 \mathrm{~h}$ at a temperature of $37^{\circ} \mathrm{C}$. After the incubation, $5 \mathrm{~mL}$ of $0.03 \mathrm{M}$ acetic acid was added and shaken for $20 \mathrm{~min}$. Next, the samples were drained through paper filters (90 mm, Munktell Ahlstrom firm). $0.4 \mathrm{~mL}$ of $25 \%$ sodium potassium tartrate, $18 \mathrm{~mL}$ of distilled water and $0.4 \mathrm{~mL}$ of Nessler's reagent were added. The wavelength urease activity was $410 \mathrm{~nm}$ and it was expressed as $\mu \mathrm{g} \mathrm{N}-\mathrm{NH} 4 \mathrm{~g}^{-1} \mathrm{DM}$ of compost/peat $18 \mathrm{~h}^{-1}$.

\subsection{Macronutrients and Micronutrients Determination}

Collected samples of substrate were chemically analysed by the universal method. Extraction of macronutrients $\left(\mathrm{N}-\mathrm{NH}_{4}, \mathrm{~N}-\mathrm{NO}_{3}, \mathrm{P}, \mathrm{K}, \mathrm{Ca}, \mathrm{Mg}, \mathrm{S}-\mathrm{SO}_{4}\right), \mathrm{Cl}$ and $\mathrm{Na}$ was carried out in $0.03 \mathrm{M} \mathrm{CH}_{3} \mathrm{COOH}$ with a quantitative 1:10 proportion of substrate to extraction solution. After extraction, the following determinations were made: $\mathrm{N}-\mathrm{NH}_{4}, \mathrm{~N}-\mathrm{NO}_{3}-$ by microdistillation according to Bremer in Starck's modification; P-colorimetrically with ammonium vanadomolybdate; $\mathrm{K}, \mathrm{Ca}, \mathrm{Na}$ - photometrically; $\mathrm{Mg}$-by atomic absorption spectrometry (ASA); $\mathrm{S}-\mathrm{SO}_{4}$-nephelometrically with $\mathrm{BaCl}_{2} ; \mathrm{Cl}$-nephelometrically with $\mathrm{AgNO}_{3}$. Micronutrients (Fe, Mn, $\mathrm{Zn}$ and $\mathrm{Cu}$ ) were extracted from the soil with Lindsay's Solution containing in $1 \mathrm{dm}^{3}: 5 \mathrm{~g}$ EDTA (ethylenediaminetetraacetic acid); $9 \mathrm{~cm}^{3}$ of $25 \%$ 
$\mathrm{NH}_{4}$ solution, $4 \mathrm{~g}$ citric acid; $2 \mathrm{~g} \mathrm{Ca}\left(\mathrm{CH}_{3} \mathrm{COO}\right)_{2} \cdot 2 \mathrm{H}_{2} \mathrm{O}$. Micronutrients were determined by the ASA method. Salinity was identified conductometrically as an electrolytic conductivity $\left(\mathrm{EC}\right.$ in $\left.\mathrm{mS} \cdot \mathrm{cm}^{-1}\right)$ (substrate:water $\left.=1: 2\right)$, and $\mathrm{pH}$-was determined by potentiometric method (substrate: water $=1: 2$ ).

At the end of the experiment, plant material was taken for chemical analysis in order to determine the microelement and macroelement content. The collected aboveground parts of the plants were dried at $45-50^{\circ} \mathrm{C}$ and then ground. For assays of total nitrogen, phosphorus, potassium, calcium and magnesium, the plant material was mineralized in concentrated sulphuric acid [21]. After mineralization of the plant samples, chemical analyses were performed using the following methods: $\mathrm{N}$-total according to Kjeldahl in a Parnas-Wagner distillation apparatus, $\mathrm{P}$ - by colorimetry with ammonium molybdate, and $\mathrm{K}, \mathrm{Ca}, \mathrm{Mg}$ by atomic absorption spectrometry (in a Carl Zeiss Jena apparatus). In the determinations of total iron, manganese, zinc and copper, the plant material was mineralized in a mixture of dioxonitric and tetraoxochloric acids (3:1 v/v) [21]. After mineralization, the $\mathrm{Fe}, \mathrm{Mn}, \mathrm{Zn}$ and $\mathrm{Cu}$ contents were determined according to ASA.

\subsection{Statistical Analyses}

Results of studies were statistically analysed using the Duncan test with inference at the significance level of $p=0.05$.

The dynamics of changes in the microorganisms number and enzymatic activity were statistically analysed. The results were analysed by two-way ANOVA using Statistica 12.0 software. The treatments and the term of analysis were the factors differentiating the traits under study to estimate the microbiological and biochemical activity parameters. Homogeneous subsets of the mean were identified by means of Tukey's test at a significance level of $p=0.05$.

Principal Component Analysis (PCA) was used to illustrate the dependence between the count of microorganisms, the enzymatic activity in the substrates, and the different morphological and chemical properties of the plants at two terms of analyses.

\section{Results}

The growth and flowering of zonal pelargonium was significantly dependent on the substrate type and related with its chemical composition.

Pelargonium cultivated in 100\% OPA (OPA I) and 100\% OPB (OPB I) compost, and also in the medium consisting of $75 \%$ of OPA (OPA II) or OPB (OPB II) was characterised by a lower leaf level (Tables 3 and 4 ).

Table 3. The influence of OPA compost on the morphological features of zonal pelargonium.

\begin{tabular}{|c|c|c|c|c|c|}
\hline Medium & $\begin{array}{l}\text { Height of Leaves } \\
\text { Layer }(\mathrm{cm})\end{array}$ & $\begin{array}{c}\text { Number of } \\
\text { Leaves }\end{array}$ & $\begin{array}{c}\text { Length of } \\
\text { Inflorescences }(\mathrm{cm})\end{array}$ & $\begin{array}{c}\text { Number of } \\
\text { Inflorescences }\end{array}$ & $\begin{array}{l}\text { Fresh Weight of } \\
\text { Inflorescences }(\mathrm{g})\end{array}$ \\
\hline Control-peat & $7.2 b^{*}$ & $9.9 \mathrm{a}$ & $10.9 \mathrm{~cd}$ & $2.0 \mathrm{~b}$ & $6.9 \mathrm{a}$ \\
\hline $100 \%$ compost & $5.9 \mathrm{a}$ & $13.0 \mathrm{~b}$ & $7.6 \mathrm{a}$ & $1.6 \mathrm{a}$ & $7.3 \mathrm{a}$ \\
\hline $\begin{array}{l}75 \% \text { compost }+ \\
25 \% \text { peat }\end{array}$ & $6.1 \mathrm{a}$ & $17.0 \mathrm{c}$ & $9.2 \mathrm{~b}$ & $2.2 \mathrm{~b}$ & $10.3 \mathrm{~b}$ \\
\hline $\begin{array}{c}50 \% \text { compost }+ \\
50 \% \text { peat }\end{array}$ & $8.2 \mathrm{c}$ & $18.9 \mathrm{c}$ & $10.1 \mathrm{~b}$ & $1.8 \mathrm{ab}$ & $20.2 c$ \\
\hline $\begin{array}{c}25 \% \text { compost }+ \\
75 \% \text { peat }\end{array}$ & $8.7 \mathrm{c}$ & $16.8 \mathrm{c}$ & $11.7 \mathrm{~d}$ & $2.3 \mathrm{~b}$ & $39.4 \mathrm{~d}$ \\
\hline
\end{tabular}

\footnotetext{
${ }^{*}$ Means followed by the same letters do not differ significantly at $p=0.05$.
} 
Table 4. The influence of OPB compost on the morphological features of zonal pelargonium.

\begin{tabular}{cccccc}
\hline Medium & $\begin{array}{c}\text { Height of Leaves } \\
\text { Layer } \mathbf{( c m})\end{array}$ & $\begin{array}{c}\text { Number of } \\
\text { Leaves }\end{array}$ & $\begin{array}{c}\text { Length of } \\
\text { Inflorescences } \mathbf{( c m})\end{array}$ & $\begin{array}{c}\text { Number of } \\
\text { Inflorescences }\end{array}$ & $\begin{array}{c}\text { Fresh Weight of } \\
\text { Inflorescences }(\mathbf{g})\end{array}$ \\
\hline Control-peat & $7.2 \mathrm{~b} *$ & $9.3 \mathrm{a}$ & $10.9 \mathrm{~b}$ & $2.0 \mathrm{~b}$ & $6.9 \mathrm{a}$ \\
\hline $\begin{array}{c}100 \% \text { compost } \\
\begin{array}{c}75 \% \text { compost }+ \\
25 \% \text { peat }\end{array}\end{array}$ & $6.4 \mathrm{a}$ & $11.3 \mathrm{a}$ & $8.4 \mathrm{a}$ & $1.6 \mathrm{a}$ & $1.9 \mathrm{ab}$ \\
\hline $\begin{array}{c}50 \% \text { compost }+ \\
50 \% \text { peat }\end{array}$ & $7.4 \mathrm{~b}$ & $16.6 \mathrm{~b}$ & $10.6 \mathrm{~b}$ & $2.1 \mathrm{~b}$ & $16.3 \mathrm{~b}$ \\
\hline $\begin{array}{c}25 \% \text { compost }+ \\
75 \% \text { peat }\end{array}$ & $9.0 \mathrm{c}$ & $17.3 \mathrm{~b}$ & $10.1 \mathrm{~b}$ & $2.2 \mathrm{~b}$ & $32.0 \mathrm{c}$ \\
\hline
\end{tabular}

${ }^{*}$ Means followed by the same letters do not differ significantly at $p=0.05$.

The smallest number of leaves was formed by the plants grown in control combination (peat substrate) and in the $100 \%$ compost as a substrate. Adding compost OPA and OPB to the peat significantly stimulated the forming of these organs. The leaf assimilation area was significantly smaller in the case of plants cultivated in the substrates consisting of $100 \%$ and $75 \%$ of compost (Tables 5 and 6 ). At $25 \%$ of OPA or OPB, the compost did not reduce the leaf area. In this case, the leaf area was similar to that of the control plants.

Table 5. The influence of OPA compost on the quality of zonal pelargonium leaves.

\begin{tabular}{ccccc}
\hline Medium & Leaf Area $\left(\mathbf{c m}^{2}\right)$ & $\begin{array}{c}\text { Fresh Weight of } \\
\text { Leaves }(\mathbf{g})\end{array}$ & $\begin{array}{c}\text { Dry Weight } \\
\text { of Leaves (g) }\end{array}$ & $\begin{array}{c}\text { Greening Index of } \\
\text { Leaves (SPAD) }\end{array}$ \\
\hline Control-peat & $24.0 \mathrm{~cd}{ }^{*}$ & $36.6 \mathrm{a}$ & $6.7 \mathrm{a}$ & $40.5 \mathrm{e}$ \\
\hline $100 \%$ compost & $10.6 \mathrm{a}$ & $35.7 \mathrm{a}$ & $5.8 \mathrm{a}$ & $21.3 \mathrm{a}$ \\
\hline $75 \%$ compost $+25 \%$ peat & $14.3 \mathrm{~b}$ & $60.1 \mathrm{~b}$ & $8.7 \mathrm{~b}$ & $26.2 \mathrm{~b}$ \\
\hline $50 \%$ compost $+50 \%$ peat & $20.5 \mathrm{c}$ & $88.5 \mathrm{c}$ & $13.2 \mathrm{c}$ & $30.7 \mathrm{c}$ \\
\hline $25 \%$ compost $+75 \%$ peat & $27.6 \mathrm{~d}$ & $67.0 \mathrm{~b}$ & $12.2 \mathrm{c}$ & $34.5 \mathrm{~d}$ \\
\hline
\end{tabular}

${ }^{*}$ Means followed by the same letters do not differ significantly at $p=0.05$.

Table 6. The influence of OPB compost on the quality of zonal pelargonium leaves.

\begin{tabular}{ccccc}
\hline Medium & Leaf Area $\left(\mathbf{c m}^{2}\right)$ & $\begin{array}{c}\text { Fresh Weight of } \\
\text { Leaves } \mathbf{( g )}\end{array}$ & $\begin{array}{c}\text { Dry Weight } \\
\text { of Leaves (g) }\end{array}$ & $\begin{array}{c}\text { Greening Index of } \\
\text { Leaves (SPAD) }\end{array}$ \\
\hline Control-peat & $24.0 \mathrm{c}^{*}$ & $36.6 \mathrm{a}$ & $6.7 \mathrm{a}$ & $40.5 \mathrm{c}$ \\
\hline $100 \%$ compost & $12.0 \mathrm{a}$ & $43.7 \mathrm{a}$ & $7.9 \mathrm{a}$ & $31.2 \mathrm{~b}$ \\
\hline $75 \%$ compost $+25 \%$ peat & $12.4 \mathrm{a}$ & $89.2 \mathrm{~b}$ & $16.5 \mathrm{~b}$ & $23.2 \mathrm{a}$ \\
\hline $50 \%$ compost $+50 \%$ peat & $19.5 \mathrm{~b}$ & $129.8 \mathrm{c}$ & $27.5 \mathrm{c}$ & $25.1 \mathrm{a}$ \\
\hline $25 \%$ compost $+75 \%$ peat & $25.0 \mathrm{c}$ & $88.7 \mathrm{~b}$ & $18.4 \mathrm{~b}$ & $39.1 \mathrm{c}$ \\
\hline
\end{tabular}

* Means followed by the same letters do not differ significantly at $p=0.05$.

The fresh and the dry matter of pelargonium cultivated in peat and in compost only, both OPA and OPB, was significantly smaller (Tables 4 and 5). The highest fresh and dry matter of the leaves was observed in the plants growing in the substrate consisting of $50 \%$ of compost and $50 \%$ of peat. The fresh weight of inflorescences was the highest in plants cultivated in peat substrates supplemented with $25 \%$ compost.

Leaf colouring reflects total chlorophyll content. In the conducted experiment, leaf colouring expressed as a SPAD unit was significantly dependent on the composition of the substrate in which the pelargonium was cultivated (Tables 4 and 5). The higher peat content in the substrate, in the case of OPA compost, the darker colouring of the leaf blade 
was observed. In the case of the other examined compost, the control plants, as well as the plants cultivated in the substrate consisting of $25 \%$ of compost and $75 \%$ of peat, did not differ significantly from each other. In other combinations, the pelargoniums formed lighter, chlorotic leaves with a low SPAD index. In the conducted experiment, the favourable influence of the tested compost on plant flowering was also observed (Tables 3 and 4).

Regardless of the compost type and its percentage in the substrate, the number of flowering plants expressed in a percentage was higher in comparison with the control group (Figure 1). The number of inflorescence shoots formed on the plants, on the other hand, did not differ significantly from the control group, with the exception of pelargoniums cultivated in the substrate consisting of the compost only (Tables 3 and 4). In this case, the plants formed slightly fewer inflorescences.

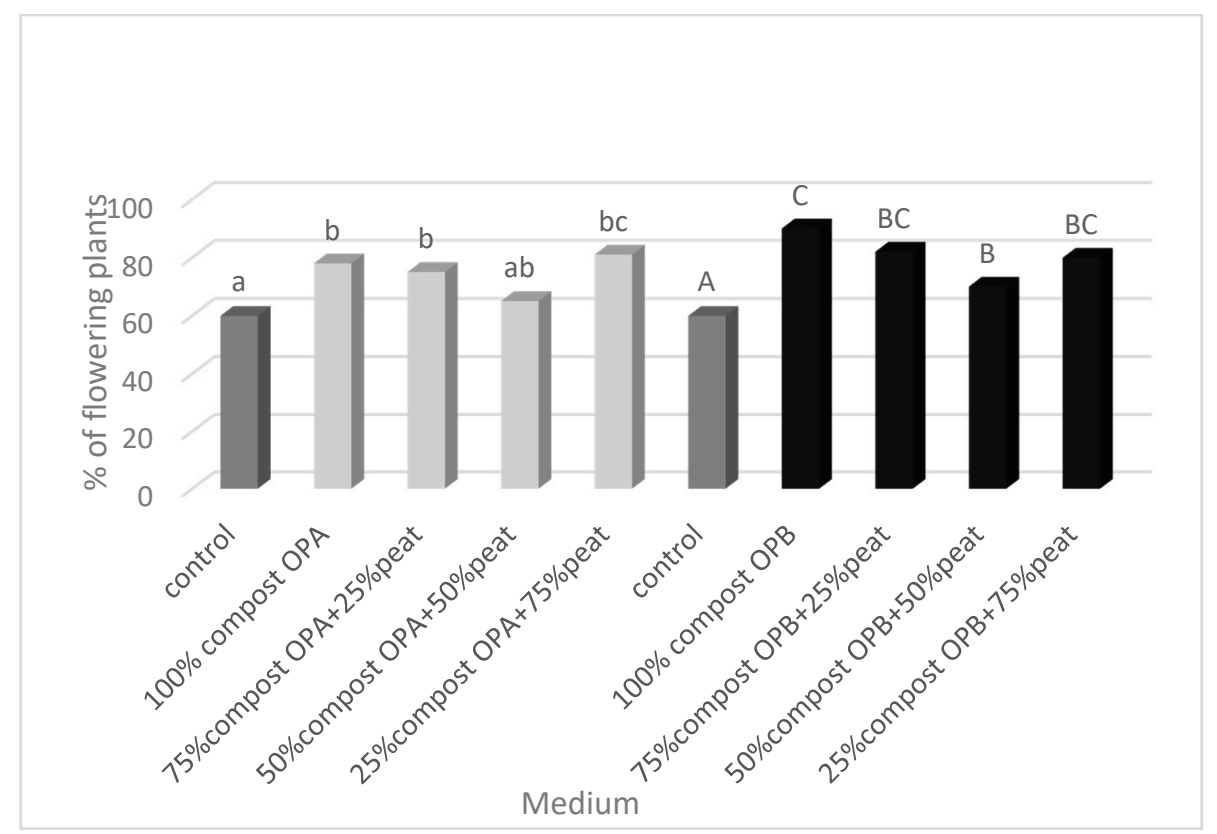

Figure 1. Percentage of flowering plants depending on the medium. Means followed by the same letters do not differ significantly at $p=0.05$.

Bacteria, actinobacteria and fungi play an important role in the mineralization of organic matter. The microbiological analyses showed that at the beginning of the experiment the count of heterotrophic bacteria in all the experimental treatments of substrates was lower than in the control treatment, which consisted of peat only (Figure 2). After cultivation, the counts of these bacteria in almost all samples of substrates were significantly lower than in the control treatment. In most of the experimental treatments, the substrates with the OPB compost had more heterotrophic bacteria than the ones with the OPA compost.

There was a statistically significant decrease in the count of actinobacteria in the substrates (Figure 3) at the end of the experiment as compared with the control sample, which consisted of $100 \%$ peat. The only exception was the treatment with the $25 \%$ content of the OPB (OPB IV) compost, where the count of actinobacteria increased significantly compared to the control treatments at the beginning of the experiment, the addition of peat to the OPA and OPB compost resulted in a decrease in the count of actinobacteria. The substrates with the OPB compost had more actinobacteria than those with the OPA compost. 


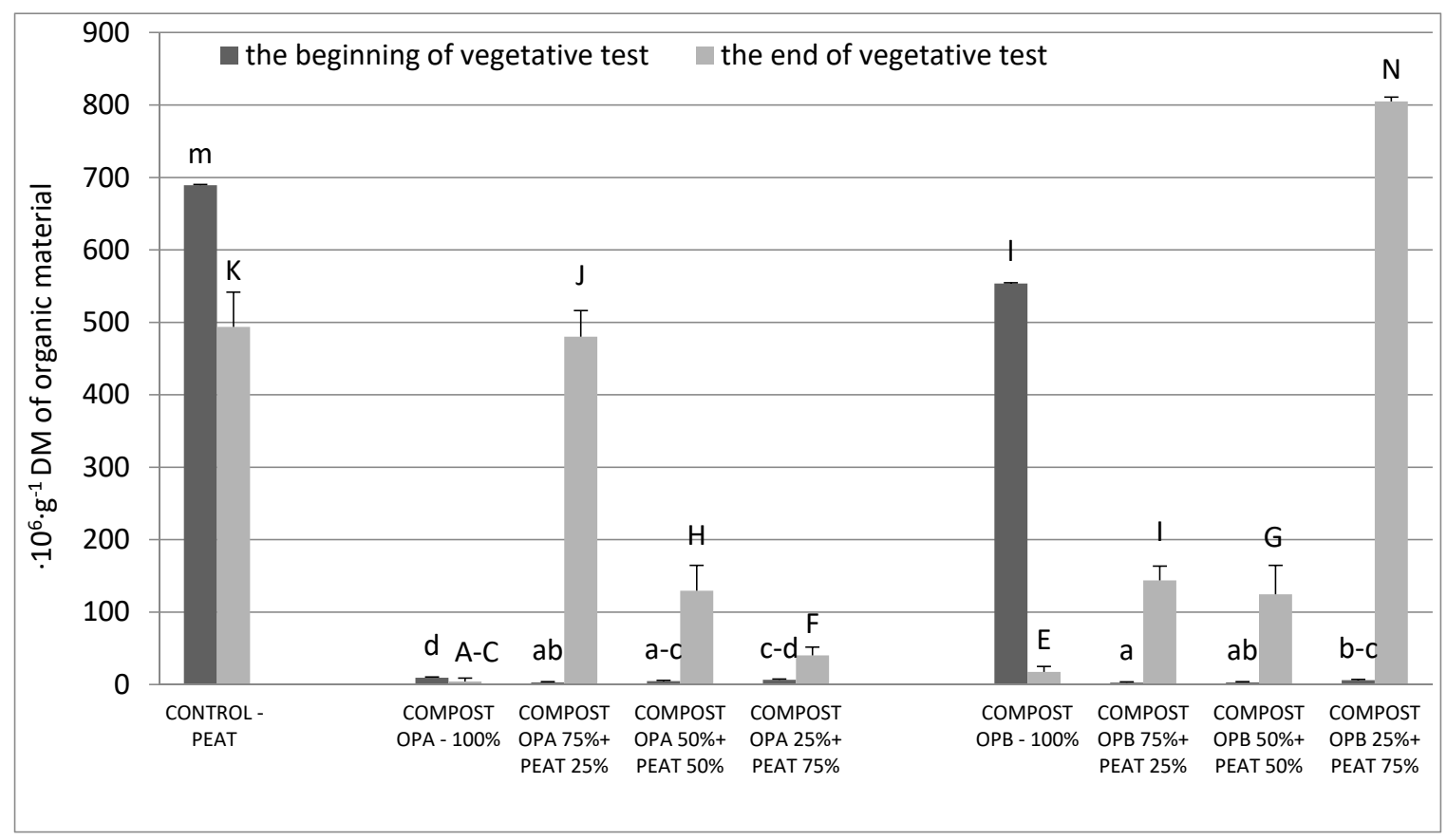

Figure 2. The changes of the total bacteria number. Means followed by the same letters do not differ significantly at $p=0.05$.

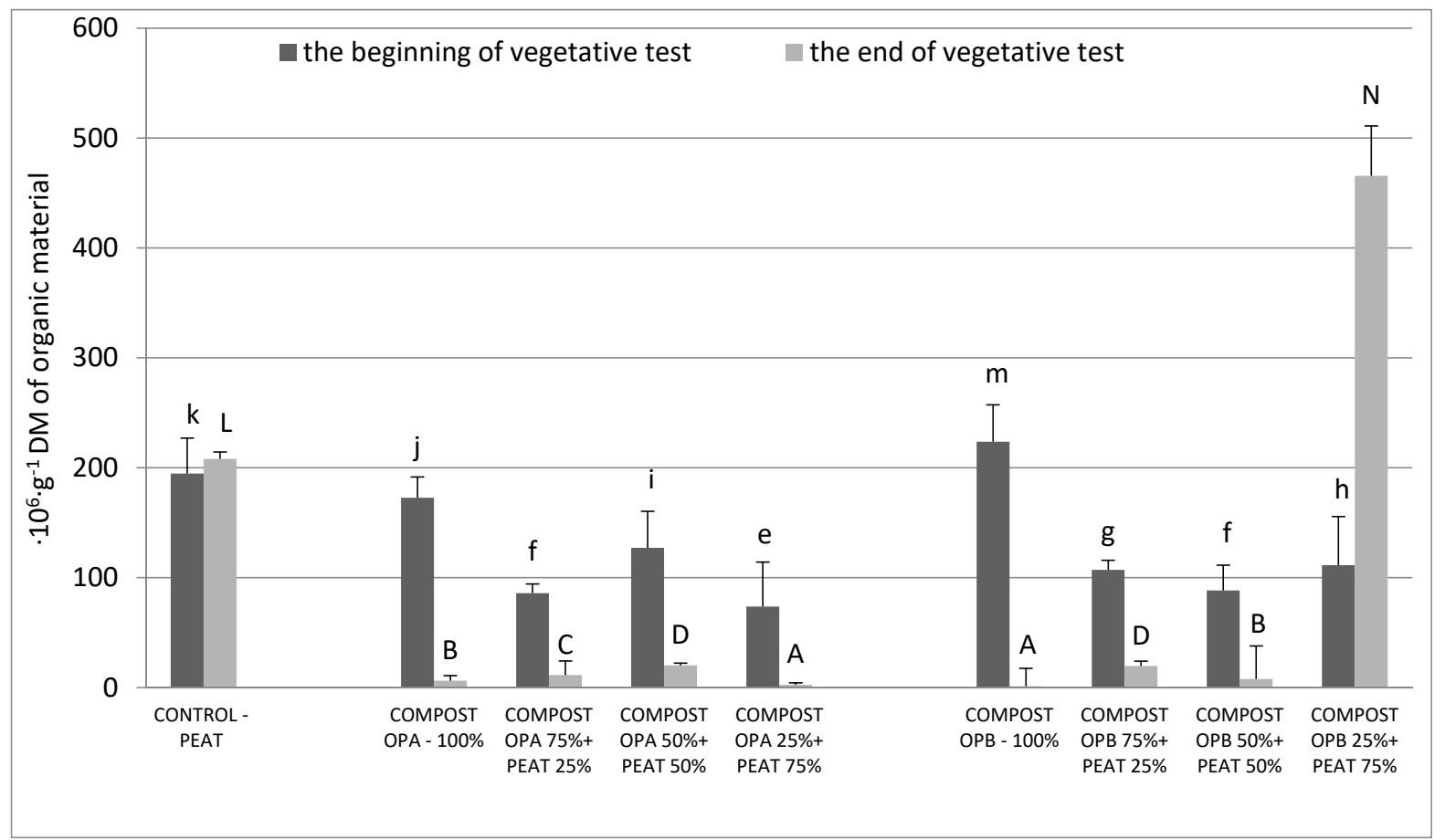

Figure 3. The changes in the number of total actinobacteria. Means followed by the same letters do not differ significantly at $p=0.05$.

At the beginning of the experiment, the count of fungi (Figure 4) in the samples with the OPA compost was higher than in those with the OPB compost. The decrease in the fungal count at the end of the experiment may have been caused by microbiological reactions and the emergence of metabolites with inhibitive properties. At the end of the experiment (second term), the highest count of fungi was found in the treatment consisting of the OPB compost (25\%) and peat $(75 \%)$. 


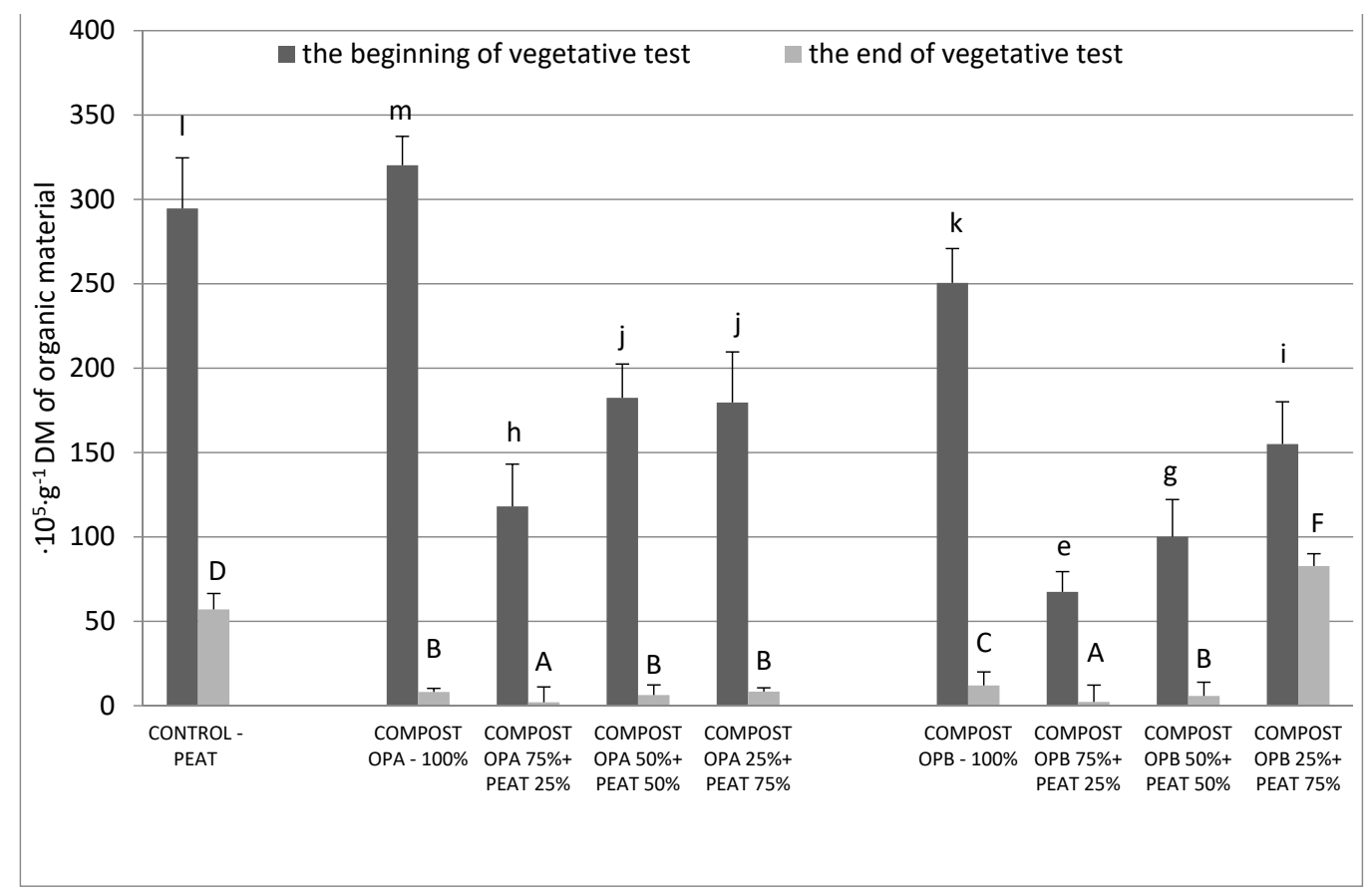

Figure 4. The changes of the total moulds number. Means followed by the same letters do not differ significantly at $p=0.05$.

The analysis of the metabolic activity of microorganisms based on the dehydrogenase activity showed that it was the highest (Figure 5) at the end of the experiment in the control treatment consisting of $100 \%$ peat. During the same phase of the experiment, there was high DHA activity in the samples with at least $50 \%$ of peat. The dehydrogenase activity level was highly significant only at the end of the experiment in the treatments containing $100 \%$ and $75 \%$ of the OPB compost.

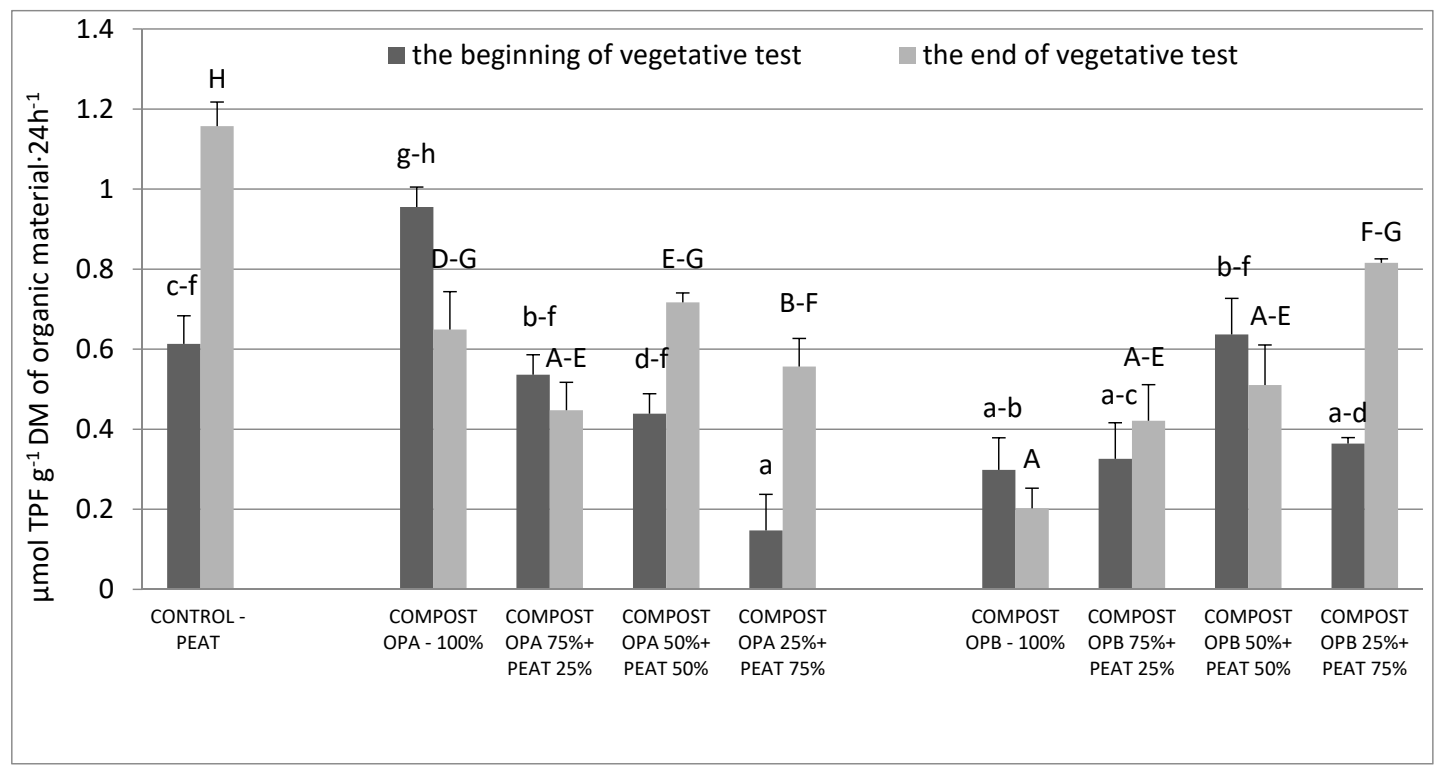

Figure 5. The changes of the dehydrogenase activity. Means followed by the same letters do not differ significantly at $p=0.05$.

The acid phosphatase level in all the treatments (Figure 6) was higher at the beginning of the experiment than at the end. This may have been caused by a decrease in the content of decomposing organic phosphorus compounds. At the end of the experiment, there were statistically significant changes in the treatments with both the OPA and OPB compost $(100 \%$ or $75 \%$ of the substrate). 


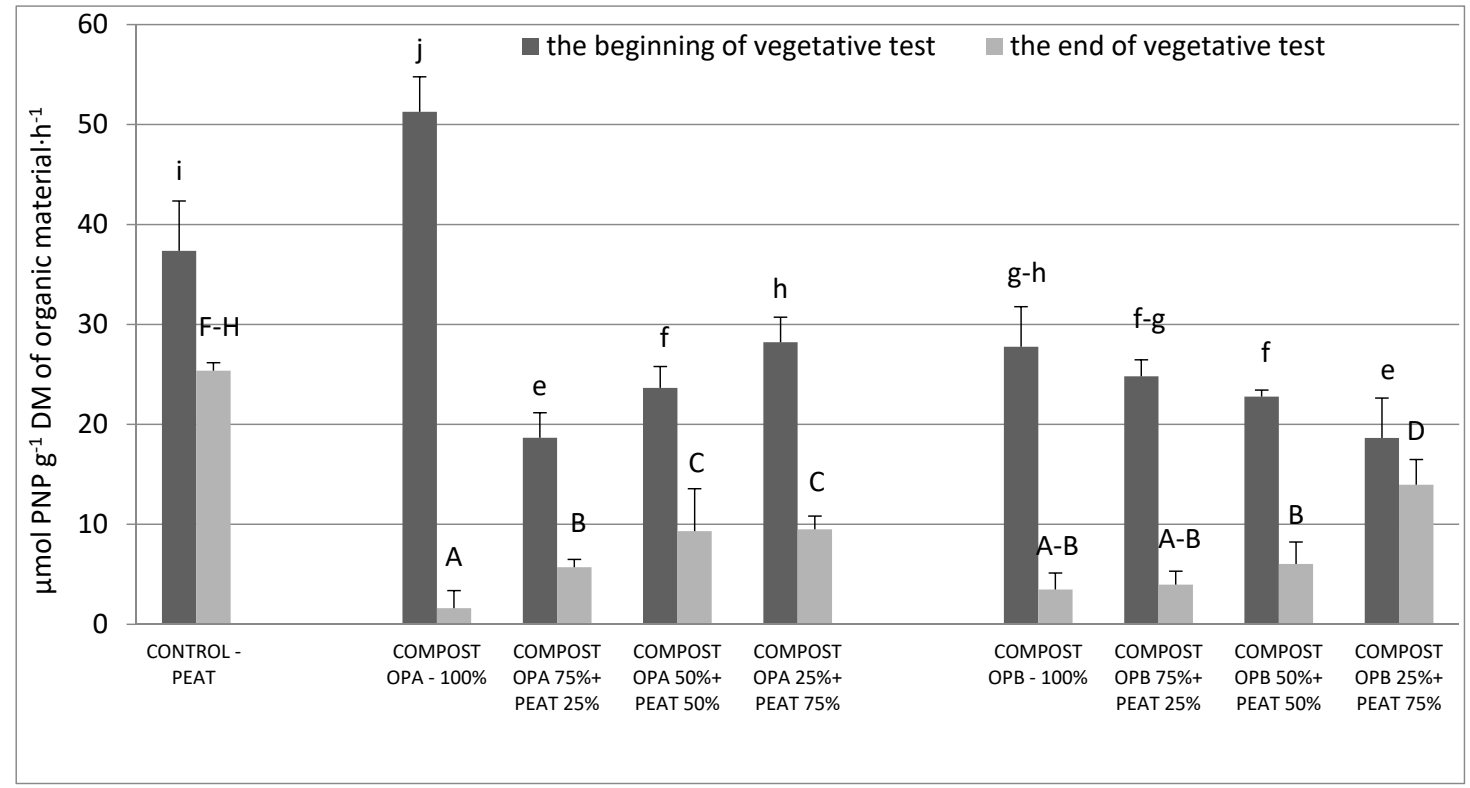

Figure 6. The changes in phosphatase activity. Means followed by the same letters do not differ significantly at $p=0.05$.

Urea and organic nitrogen compounds in the soil and in other environments are hydrolysed under the influence of urease produced by microorganisms. The activity of the enzymes involved in nitrogen transformations in the soil environment can be used as an indicator of its bioactivity, the intensity of these transformations and the availability of nitrogen to plants. Urease activity changed in nearly all the experimental treatments (Figure 7). At the end of the experiment, urease activity was higher than at the beginning. The urease activity was lower than at the beginning of the experiment only in the treatments with the $100 \%$ of OPA or OPB compost. A higher peat content in the treatments with both compost variants stimulated the urease activity. However, only the samples with the OPB compost mixed with peat at a ratio of 1:1 and 1:3 exhibited higher urease activity than the control sample ( $100 \%$ peat). These changes were not statistically significant.

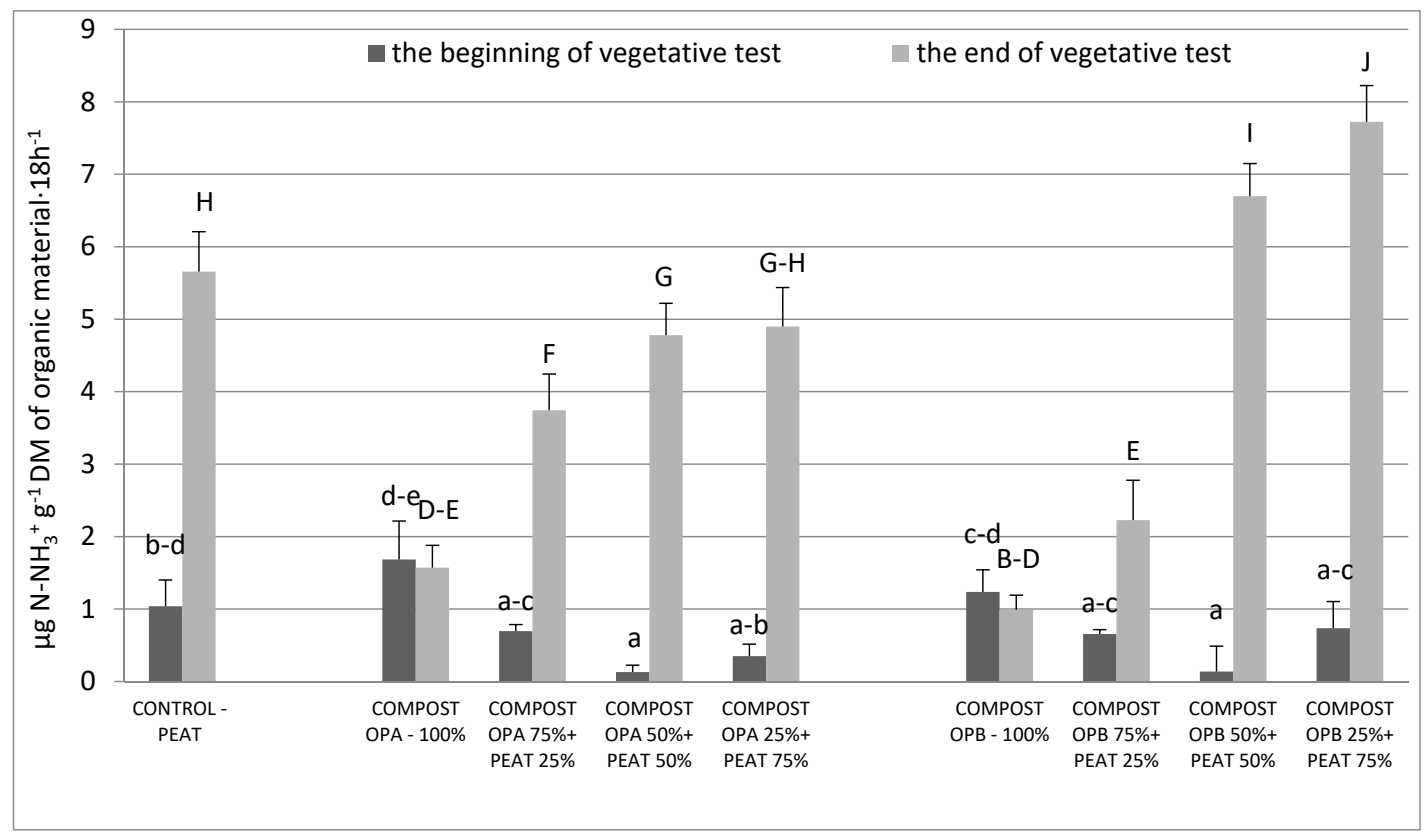

Figure 7. The changes in urease activity. Means followed by the same letters do not differ significantly at $p=0.05$. 
Simple correlation analysis and principal component analysis (PCA) were used to estimate cause-and-effect relationships between the parameters under investigation (Figure 8).
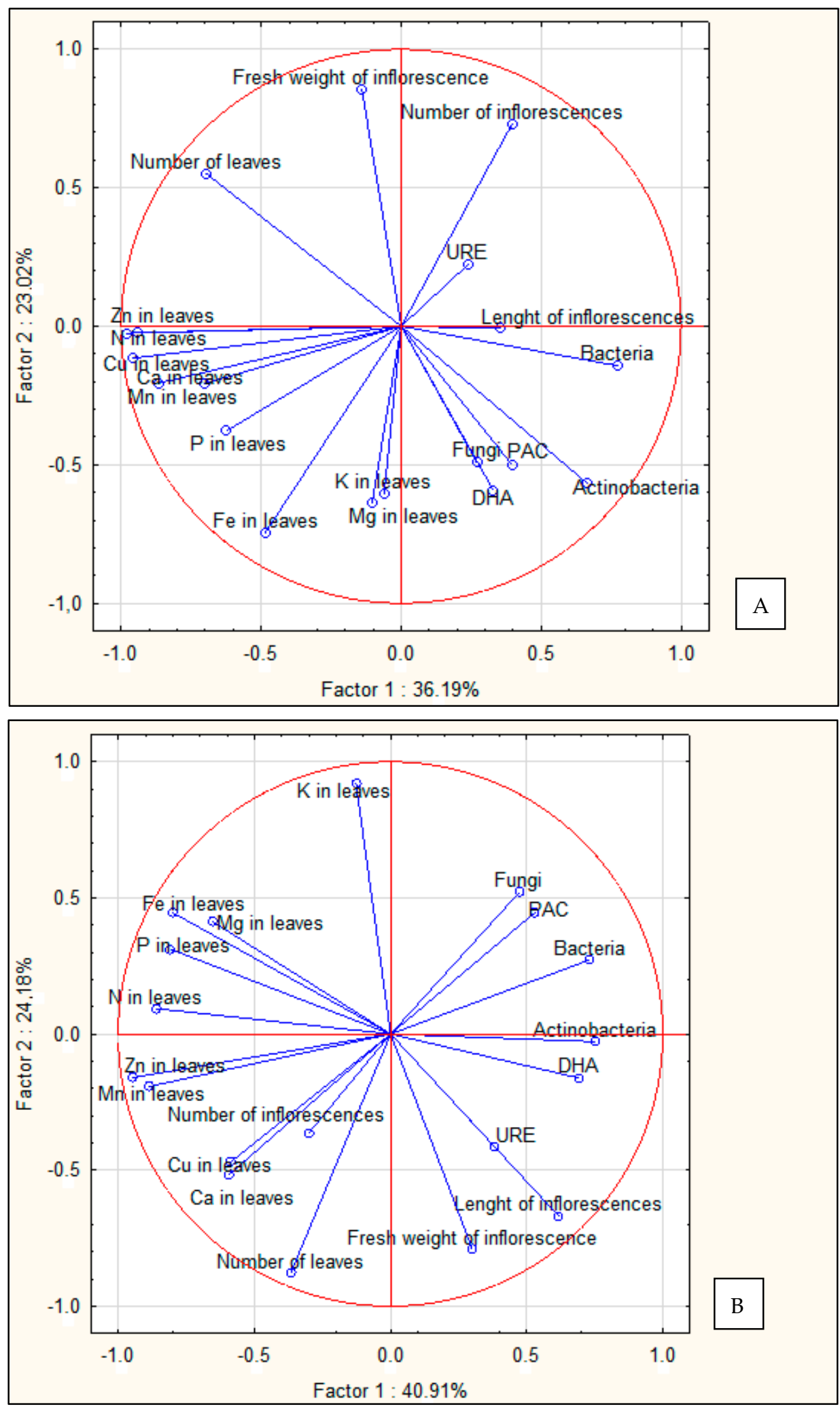

Figure 8. Dependence between the enzymatic activity, the number of groups of microorganisms and the morphological and chemical parameters of plants applied in the experimental at consecutive terms of analyses (PCA); (A)—OPA Compost, (B) - OPB Compost. 
The PCA was used to show regularities between independent variables. The components, which were a linear treatment of the variables under analysis, were calculated. A detailed analysis of principal components provides the possibility to indicate the initial variables, which are a frame of reference for the other variables. It is necessary to stress the fact that in the new coordinate system, a considerable part of variables can be explained, i.e., more than $50 \%$.

The principal component analysis showed that the dependencies between the parameters under analysis were related to the composition of the compost. In the treatments with the OPA compost, there was a strict, positive relation between the count of actinobacteria and bacteria. There was no relation between the growth and development of bacteria and moulds. However, in the treatments with the OPB compost, there was a relationship between all the groups of microorganisms under analysis. Apart from that, the research results showed that when the OPA compost was used, the dehydrogenase activity level was influenced only by actinobacteria, whereas the alkaline phosphatase activity was mostly affected by moulds and secondly by actinobacteria. The research did not reveal a positive relationship between the urease activity and the count of the groups of microorganisms under analysis. There were slightly different relations between the test parameters in the substrates with the OPB compost. The DHA and URE levels were positively correlated with the growth and development of bacteria and actinobacteria, whereas the PAC level was positively correlated with the count of all groups of microorganisms. The principal component analysis also showed that when the crops were grown on the substrates containing both variants of compost, the number of leaves, the fresh weight of inflorescence and the content of $\mathrm{N}, \mathrm{Fe}, \mathrm{Ca}, \mathrm{Zn}, \mathrm{Mn}$ and $\mathrm{Cu}$ in the leaves were negatively correlated with the count of bacteria and actinobacteria. This might be evidence that microorganisms competed with the plants for nutrients in the substrate.

The principal component analysis also showed that when the crops were grown on the substrates containing both variants of compost, the number of leaves, the fresh weight of inflorescence and the content of $\mathrm{N}, \mathrm{Fe}, \mathrm{Ca}, \mathrm{Zn}, \mathrm{Mn}$ and $\mathrm{Cu}$ in the leaves were negatively correlated with the count of bacteria and actinobacteria. This might be evidence proving that microorganisms competed with the plants for nutrients in the substrate.

The substrate chemical composition varied according to the type of the wood waste and its volume ratio with peat (Table 2). At the beginning of the experiment, the tested substrates were characterised by the proper contents of calcium, iron, manganese and copper and, simultaneously by the excess contents of nitrogen and zinc, and deficits of phosphorus, potassium and magnesium. The OPA and OPB substrate $\mathrm{pH}$ varied according to the content of peat substrate: the higher its content the higher $\mathrm{pH}$ was. After the end of the vegetative experiment, a general tendency towards a decline in nitrogen content was observed. Moreover, the iron, manganese and zinc content decreased (OPB), while phosphorus (OPA), potassium, calcium and zinc (OPA) contents remained stable, and phosphorus (OPB), magnesium, copper and chloride contents increased. The $\mathrm{pH}$ changes of the substrate were multidirectional. In our research, the contents of nitrate nitrogen, manganese and zinc in the substrate decreased while the copper content increased at the same time.

The studied substrates significantly modified the content of macro and microelements (with the exception of zinc) in plants (Table 7).

Macroelements. Depending on the substrate used, the nitrogen content in pelargonium leaves was determined and it ranged from $1.51 \%$ (control) to $2.71 \% \mathrm{~N}$ (OPB I). Meanwhile, the plants cultivated in the substrate composed form peat $(0.35 \% \mathrm{P})$ and in the mixtures with its high content (OPA IV and OPB IV- $0.36 \%$ P each) contained the lowest levels of phosphorus, while those cultivated in OPB I were characterised by the highest phosphorus content $(0.53 \% \mathrm{P})$. The lowest potassium content was found in plants cultivated in OPB IV $(0.45 \% \mathrm{~K})$ and significantly the highest in OPA II and III and in OPB I $(0.96,0.95$ and $1.00 \% \mathrm{~K}$, respectively). In our studies, the lowest content of calcium was found in the control combination (2.26\% Ca) and in OPA II and IV (2.29 and 2.58\% Ca respectively) 
and also in OPA I $(2.48 \% \mathrm{Ca})$ while the highest amount was found in OPB II ( $3.67 \% \mathrm{Ca})$. The lowest content of magnesium was determined for OPA II and IV ( $0.20 \% \mathrm{Mg}$ each) while the highest amount was determined for OPB I $(0.28 \% \mathrm{Mg})$.

Table 7. The influence of medium on the content of macro- and microelements in the aboveground parts of plants.

\begin{tabular}{|c|c|c|c|c|c|c|c|c|c|}
\hline \multirow{2}{*}{ Medium } & $\mathbf{N}$ & $\mathbf{P}$ & $\mathbf{K}$ & $\mathrm{Ca}$ & $\mathrm{Mg}$ & $\mathrm{Fe}$ & Mn & $\mathrm{Zn}$ & $\mathrm{Cu}$ \\
\hline & \multicolumn{5}{|c|}{ \% Oven Dry Mass } & \multicolumn{4}{|c|}{$\mathrm{mg} \cdot \mathrm{kg}^{-1}$ Oven Dry Mass } \\
\hline Control-peat & $1.51^{\mathrm{a}}$ & $0.35^{\mathrm{a}}$ & $0.90^{\mathrm{ab}}$ & $2.26^{\mathrm{a}}$ & $0.23^{\mathrm{ab}}$ & $53.3^{a b c}$ & $60.1^{a b}$ & $27.9^{\mathrm{a}}$ & $4.00^{\mathrm{a}}$ \\
\hline \multicolumn{10}{|c|}{ OPA } \\
\hline $100 \%$ compost & $2.10^{\mathrm{ab} *}$ & $0.45^{\mathrm{ab}}$ & $0.84^{\mathrm{ab}}$ & $2.95^{\mathrm{ab}}$ & $0.26^{\mathrm{ab}}$ & $92.1^{\mathrm{c}}$ & $197.8^{c}$ & $305.7^{\mathrm{c}}$ & $4.90^{b c}$ \\
\hline $75 \%$ compost $+25 \%$ peat & $1.96^{\mathrm{ab}}$ & $0.44^{\mathrm{ab}}$ & $0.96^{\mathrm{b}}$ & $2.29^{a}$ & $0.20^{\mathrm{a}}$ & $70.2^{b c}$ & $228.8^{c}$ & $266.2^{c}$ & $4.80^{b c}$ \\
\hline $50 \%$ compost $+50 \%$ peat & $2.08^{a b}$ & $0.41^{\mathrm{ab}}$ & $0.95^{\mathrm{b}}$ & $3.04^{a b}$ & $0.22^{a b}$ & $54.7^{\text {bc }}$ & $222.4^{\mathrm{c}}$ & $267.6^{c}$ & $4.80^{b c}$ \\
\hline $25 \%$ compost $+75 \%$ peat & $1.91^{\mathrm{ab}}$ & $0.36^{\mathrm{a}}$ & $0.55^{\mathrm{ab}}$ & $2.58^{\mathrm{a}}$ & $0.20^{\mathrm{a}}$ & $44.2^{\mathrm{ab}}$ & $103.8^{\mathrm{b}}$ & $213.6^{c}$ & $4.50 \mathrm{abc}$ \\
\hline Mean & $2.01^{\mathrm{a} * *}$ & $0.42^{\mathrm{a}}$ & $0.82^{\mathrm{a}}$ & $2.71^{\mathrm{a}}$ & $0.22^{\mathrm{a}}$ & $65.3^{a}$ & $188.2^{\mathrm{a}}$ & $263.3^{\mathrm{a}}$ & $4.75^{\mathrm{a}}$ \\
\hline \multicolumn{10}{|c|}{ OPB } \\
\hline $100 \%$ compost & $2.71^{b *}$ & $0.53^{b}$ & $1.00^{b}$ & $2.48^{a}$ & $0.28^{b}$ & $80.2^{b c}$ & $142.3^{c}$ & $261.5^{c}$ & $4.20^{\mathrm{ab}}$ \\
\hline $75 \%$ compost $+25 \%$ peat & $2.52^{b}$ & $0.48^{a b}$ & $0.58^{\mathrm{ab}}$ & $3.67^{b}$ & $0.26^{\mathrm{ab}}$ & $82.4^{\text {bc }}$ & $221.7^{c}$ & $305.7^{\mathrm{c}}$ & $4.50^{a b c}$ \\
\hline $50 \%$ compost $+50 \%$ peat & $2.36^{\mathrm{b}}$ & $0.44^{\mathrm{ab}}$ & $0.68^{\mathrm{ab}}$ & $2.81^{\mathrm{ab}}$ & $0.25^{\mathrm{ab}}$ & $62.8^{b c}$ & $234.2^{c}$ & $300.7^{c}$ & $5.10^{\mathrm{c}}$ \\
\hline $25 \%$ compost $+75 \%$ peat & $1.93^{\mathrm{ab}}$ & $0.36^{\mathrm{a}}$ & $0.45^{\mathrm{a}}$ & $2.70^{a b}$ & $0.22 \mathrm{ab}$ & $27.9^{\mathrm{a}}$ & $51.0^{\mathrm{a}}$ & $115.0^{\mathrm{b}}$ & $4.20^{\mathrm{ab}}$ \\
\hline Mean & $2.38^{b * *}$ & $0.45^{\mathrm{a}}$ & $0.68^{\mathrm{a}}$ & $2.91^{\mathrm{a}}$ & $0.25^{\mathrm{a}}$ & $63.3^{a}$ & $162.3^{\mathrm{a}}$ & $245.7^{\mathrm{a}}$ & $4.50^{\mathrm{a}}$ \\
\hline
\end{tabular}

*Values in columns followed by the same letters do not differ significantly at $p=0.05$. ${ }^{* *}$ means followed by the same letters do not differ significantly at $p=0.05$.

Microelements. The lowest iron contents were found in plants cultivated in OPB IV (27.9 mg Fe $\left.\cdot \mathrm{kg}^{-1}\right)$, and the highest in the case of OPA I (92.1 mg Fe $\left.\cdot \mathrm{kg}^{-1}\right)$. As far as manganese is concerned, the lowest amounts of this element were found in the leaves of plants cultivated in OPB IV (51.0 $\mathrm{mg} \mathrm{Mn} \cdot \mathrm{kg}^{-1}$ ), and the highest for OPA I-III (from 142.3 to $\left.234.2 \mathrm{mg} \mathrm{Mn} \cdot \mathrm{kg}^{-1}\right)$. Significantly, the lowest amounts of zinc were found in the plants in the control combination $\left(27.9 \mathrm{mg} \mathrm{Zn} \cdot \mathrm{kg}^{-1}\right)$, and the highest in all the other combinations (with the exception of OPB IV) (213.6-305.7 mg Zn $\cdot \mathrm{kg}^{-1}$ ). The lowest amounts of copper were found in the plants in the control combination and the highest with the use of OPB III as the substrate $\left(4.00\right.$ and $\left.5.10 \mathrm{mg} \mathrm{Cu} \cdot \mathrm{kg}^{-1}\right)$.

\section{Discussion}

Our study showed the considerable potential of using compost from post-consumer wood on a substrate component in the cultivation of zonal pelargonium. At 75\%, 50\%, 25\% of OPA or OPB compost pelargonium produces a greater number of leaves than control plants and when growing in the $100 \%$ compost (Tables 3 and 4). The stimulating influence of urban waste compost on the number of leaves is confirmed by Ribeiro et al. [22].

The leaf blade is a plant organ that is extremely significant in the photosynthesis process. In this experiment, regardless of the compost treatment, the leaf area of the plants cultivated in $100 \%$ compost and in the medium with either $75 \%$ compost OPA or OPB was significantly smaller compared with the control group (Tables 5 and 6). A similar tendency in the cultivation of canna lilies was observed by Wróblewska et al. [23].

According to Ribeiro et al. [22], the dry matter of the terrestrial part of the plant (shoots, leaves and inflorescences) was higher in comparison with the control group in the case of 10, 20,30 and $40 \%$ urban waste compost content in the substrate. The same authors claim that the higher addition of compost (50\%) to peat can have an unfavourable effect, resulting in the decrease in the dry matter of pelargonium terrestrial part.

Plants growth in the substrate containing $25 \%$ compost produced dark green leaves (Tables 5 and 6). Darkness of leaves could be related with the content of magnesium and also ratios between calcium and magnesium in the substrate. Plants grown in substrates with a higher proportion of OPA or OPB compost had a low nitrogen content in the leaves, 
which was reflected in low SPAD values. The values of SPAD depend significantly on the nutrition of plants with nitrogen [24,25]. In the study conducted by Zawadzińska et al. [26] the highest leaf greenness index was noted in interspecific pelargonium cultivated in peat enriched with $20 \%$ of wood fiber. However, Wolna-Maruwka et al. [11] and Wróblewska et al. $[27,28]$ stated that SPAD depends on the compost composition and its percentage in the substrate used for plant cultivation.

Our study demonstrated that plants grown in the $100 \%$ compost produced fewer inflorescences than other plants (Tables 3 and 4). Others plants revealed a similar number of inflorescences when compared with the control. According to the literature, the influence on the flowering process is significantly dependent on the species, compost composition and its percentage in the substrate $[11,23,26,27]$.

Enzymatic activity and the total counts of microorganisms in compost are defined as substrate biological activity. Changes in the enzymatic activity in these substrates reflect environmental disturbances affecting both the medium and plants. Microbial colonization of substrates highly depends on their abundance in nutrients [28], which was also reflected by the analysis of the counts of bacteria, actinobacteria and fungi in our research, (Figures 2 and 4). For example, bacteria in the substrates with the OPB compost multiplied more intensively than in those with the OPA compost. The principal component analysis (PCA) also showed a strong relationship between the groups of microorganisms under study, but only in the treatments with the OPB compost (Figure 8).

This phenomenon may have been caused by a different chemical composition of the substrates and by the presence of pelargonium root exudates, whose qualitative and quantitative composition depends on the plant's development phase. According to Bais et al. [29] and Vallence et al. [30], root exudates may either stimulate or retard the plant's development and microbiological activity in the substrate.

In the second period of analysis, the highest abundance of microorganisms in the treatment consisting of $75 \%$ of peat and $25 \%$ of OPB compost may have been caused by relatively high $\mathrm{pH}$ of the compost (6.1) and a high calcium content (Table 2). These environmentbuffering properties and the regulation of ion exchange improved the bacterial absorption of elements, e.g., phosphorus [31].

Actinobacteria are very important microorganisms colonizing all ecosystems, both natural and artificial. They have the ability to mineralize both simple and complex organic compounds and their metabolites have either retarding or stimulating effect on the remaining microbiome present in the environment [32].

As was the case with heterotrophic bacteria, the count of actinobacteria depended on both the type of the experimental treatment and the term of analyses (Figure 3). Actinobacteria also proliferated more intensively in the treatment with the OPB compost, but, unlike bacteria, it was at the first term of analyses.

The fluctuations in the counts of actinobacteria in the experimental treatments may have been caused by the qualitative and quantitative composition of root exudates, which influence the physicochemical properties of the substrate and multiplication of microorganisms [11]. They may also have been caused by the chemical composition of the substrates (compost or peat).

Apart from eubacteria and actinobacteria, fungi also play an essential role in the circulation of nutrients in the substrate. According to Howell [33], fungi affect the production of enzymes, which can inhibit the development of plant pathogens. The total count of moulds (Figure 4) in all the experimental treatments (especially in the treatment with the OPA compost) was higher at the beginning of the experiment than at the end. Wolna-Maruwka et al. [34] observed a similar interdependence. The metabolic activity of microorganisms is manifested by their enzymatic activity $[35,36]$. As various researchers observed, the recognition of enzymatic activity of the substrate gives an objective image of undergoing processes [37-40]. Nowadays, it is assumed that soil fertility and productivity can be measured to a greater extent by its enzymatic activity than other biological indicators, such as the counts or biomass of microorganisms [35]. 
As the dehydrogenase activity significantly affects the functioning of microorganisms, it is commonly used as an indicator of the microbial activity in substrates. According to Brzezińska and Włodarczyk [41], the enzymatic activity determines the physiological condition of microorganisms. The dehydrogenase activity level determines the rate of oxidoreductive changes in substrates [42].

The results of our experiment showed that the dehydrogenase activity (Figure 5) was determined by both the term of analyses and the type of experimental treatment, which was in line with the findings of the study by Wolna-Maruwka et al. [11]. During the experiment, the highest DHA was recorded in the control treatment at the second term of analyses. This indicates the inhibitory effect of the compost on the dehydrogenase activity. As was the case with the DHA, the highest phosphatase activity (Figure 6) was also noted in the control treatment (peat without additives), but at the first term of the study.

Phosphatases are another class of enzymes that significantly affect the mineralization of organic matter. They stimulate chemical changes of phosphorus compounds into inorganic phosphates $\left(\mathrm{HPO}_{4}{ }^{-2}\right.$ and $\left.\mathrm{H}_{2} \mathrm{PO}_{4}{ }^{-2}\right)$, which are directly accessible to plants. The phosphatase activity in the soil environment reflects the enzymatic activity related with soil colloids and humus substances, free phosphatases in soil solution and phosphatases linked to live and dead cells of plants and microorganisms [43].

Urease significantly affects the mineralization of organic matter, especially nitrogencontaining matter. The biochemical analyses showed that the highest urease activity (Figure 7), as with the counts of bacteria and actinobacteria, was in the treatment consisting of peat $(75 \%)$ and OPB compost $(25 \%)$ at the second term of analyses. The PCA also showed (Figure 8) a strong positive correlation between the URE activity and the counts of bacteria and actinobacteria in the treatments with the OPB compost. These experimental treatments were characterized by high enzymatic activity during the final phase of the experiment. This may have been caused by the presence of nitric root exudates. According to Bais et al. [29] and Dabek-Szreniawska et al. [44], the composition of root exudates may stimulate the microbial production of ureases due to plants' higher demand for nitrogen.

The studied substrates significantly modified the content of macro and microelements (with the exception of zinc) in plants what was confirmed by previously conducted research into the usage of wood industry waste in plant cultivation [45]. In our studies, the content of nitrogen varied depend on the treatment from 1.51 to $2.71 \%$, meanwhile phosphorus from $0.35 \% \mathrm{P}$ to $0.53 \% \mathrm{P}$. All of the literature sources report higher contents of nitrogen the pelargium plant. Determined contents were significantly lower from those reported by Kleiber and Schroeter-Zakrzewska [46], who determined on average 3.85-4.20\% N, Digat and Lemaire [47] (3.89-4.50\% N), and also Lemaire and Darigues [48]-3.60\% N on average. Kreij et al. [49] also designated much higher nitrogen contents (3.30-4.76\% N), simultaneously pointing to the fact that the nitrogen content in pelargonium leaves below $2.38 \%$ is insufficient-in most examined substrates (except for OPB I-III) designated levels were significantly lower.

The content of nitrogen in studied substrates were relatively high-So the possibly reason of quite low nitrogen content in plants could be biological sorption by microorganisms. The determined phosphorus contents in leaves were similar to the range reported by Kreij et al. [49] and Digat and Lemaire [47] (0.40-0.77\% and $0.43-0.53 \%$ P, respectively). They were also similar to the standard contents drawn up by Orange Laboratory [50] (as cited in Nowosielski (1974)). According to this source, phosphorus contents exceeding $0.8 \%$ $P$ should be regarded as excessive. Lemaire and Darigues [48] give the average content of this macroelement, which, in case of pelargonium, is $0.52 \%$ P. Lis-Krzyścin [51] observed the decline in phosphorus content in the leaves of Pelargonium $x$ hortorum from $0.48 \%$ to $0.28 \% \mathrm{P}$ during the vegetation process. Significantly lower contents are reported by Kleiber and Schroeter-Zakrzewska [46] in the research on pelargonium.

Potassium content ranged from $0.45 \% \mathrm{~K}$ to $1.00 \% \mathrm{~K}$. Significantly higher contents were determined by Digat and Lemaire [47] in their research $(5.01-5.61 \% \mathrm{~K})$, and Lemaire and Darigues [ 48$]-3.25 \% \mathrm{~K}$ on average. In all studied combinations, the potassium contents 
were much lower than the contents $(2.32-4.16 \% \mathrm{~K})$ reported by Kleiber and SchroeterZakrzewska [46] and Kreij et al. [49] 2.50-4.88\% K. Kreij et al. [49] determined 0.62\% K as the threshold deficit content while the Orange Laboratory states that the contents below $1.7 \% \mathrm{~K}$ should be treated as deficient where the standard contents are at the level of $2.6 \% \mathrm{~K}$. Lis-Krzyścin [51], for the mean value of examined combinations, found a lower concentration of this element with the plant ageing from $3.99 \%$ to $2.04 \% \mathrm{~K}$.

In our studies, the determined calcium content in plants were quite varied and ranged from $2.26 \%$ to $3.67 \%$. The examined plants were characterised by a significantly higher calcium content than the ones reported by Kleiber and Schroeter-Zakrzewska [46] (1.47-2.01\% Ca) and Kreij et al. [49] 0.80-1.20\% Ca. Similarly the calcium contents were higher than those reported by Digat and Lemaire [47] (0.83-1.48\% Ca), and also by Lemaire and Darigues [48] (1.17\% Ca on average). The Orange Laboratory states that the deficient content of this element is below $0.7 \%$ and the excessive ones over $2.5 \%$ Ca. Lis-Krzyścin [51] points out that, as in the case of most plants, the dynamics of the calcium content in pelargonium leaves grows together with the ageing process (from 2.35 to $2.56 \% \mathrm{Ca}$ ). Comparing to our studies Digat and Lemaire [47] give similar contents of magnesium in plants $(0.17-0.22 \%$ $\mathrm{Mg}$ ). These contents are in the lower range of optimal contents given by Kreij et al. [49]. They also resemble the average magnesium content given by Lemaire and Darigues [48]. Also Orange Laboratory determines the average contents at the level of $0.2 \%$ as the standard ones, pointing out simultaneously that the contents $>0.4 \% \mathrm{Mg}$ are excessive. The Magnesium contents determined in the study are within the average range of this element content $(0.15-0.24 \% \mathrm{Mg})$ given by Lis-Krzyścin [51].

Microelements. The determined contents of iron were much lower than the ones reported by Kleiber and Schroeter-Zakrzewska [52]. They were also slightly lower than the ones reported by Digat and Lemaire [47]. Meanwhile Kreij et al. [49] report that the insufficient manganese content in the pelargonium leaves are below $11 \mathrm{mg} \mathrm{Mn} \cdot \mathrm{kg}^{-1}$, while optimal contents are within the range of $44-137 \mathrm{mg} \mathrm{Mn} \mathrm{kg}^{-1}$ leaf dry matter what was comparable to contents determined in our studies. Significantly the lowest amounts of zinc in our studies it were found in the plants in the control combination $\left(27.9 \mathrm{mg} \mathrm{Zn} \cdot \mathrm{kg}^{-1}\right)$, and the highest in all the other combinations (with the exception of OPB IV) (213.6-305.7 $\mathrm{mg} \mathrm{Zn} \cdot \mathrm{kg}^{-1}$ ). Except for the control combination the determined zinc contents were over ten times higher than those reported by Kleiber and Schroeter-Zakrzewska [52] who found

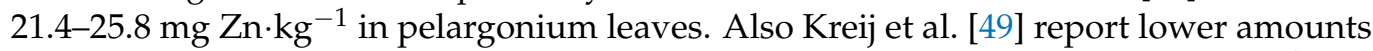

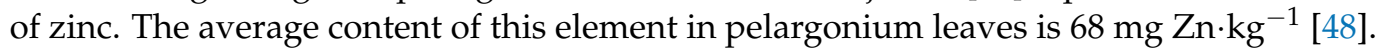
The determined copper contents were similar to these reported by Kleiber and SchroeterZakrzewska [52]. According to Kreij et al. [49] the content below $5.7 \mathrm{mg} \mathrm{Cu} \cdot \mathrm{kg}^{-1}$ is not sufficient for the optimal nutrition with this element where the best possible nutrition ranges from 6.4 to $19 \mathrm{mg} \mathrm{Cu} \cdot \mathrm{kg}^{-1}$. Lemaire and Darigues [48], on the other hand, give almost twice as high copper content as the one determined in the own research. As far as the mean of the examined substrates is concerned the nutrition condition of the plants did not differ significantly with the exception of nitrogen whose contents were highest in plants cultivated in OPB. The usefulness of OPA and OPB for plant cultivation was previously examined by Wróblewska et al. [10,53]. The author found higher amounts of zinc in the plants cultivated in the substrate with OPB compost when compared to OPA [9]. This was not confirmed in the own research. In comparison with the control combination the examined compost variants had a favourable effect onto the increase in the contents of nitrogen, phosphorus, calcium, iron, manganese and zinc with simultaneous decrease in the amounts of potassium and almost unchanged content of manganese and copper in pelargonium leaves. However, despite the high nitrogen content in the substrate the nutritional state of the plants as far as this element is concerned, should be considered as improper. As far as phosphorus is concerned, regardless of its relatively low content in the substrate, its amount in the leaves was within the standard range reported by other authors. In the case of potassium there seems to be an interdependence of its insufficient presence in the substrate with the improper plant nutrition. Despite the proper amount of 
calcium in the substrate, the amount of this macroelement in the leaves when compared with the previous research by other authors should be considered as excessive. In all examined combinations the magnesium contents in the plants were correct. In terms of iron, manganese, zinc and copper, divergent reference data was found. The application of compost made from wood materials in ornamental plant cultivation in pots can be considered as a valuable alternative to the use of peat. However, the precondition of their usage is conducting controlled plant nutrition program based on the cyclical chemical analyses of the used substrates. The use of alternative organic substrates can contribute to the reduction of the intensity of peat exploitation for horticulture production, which can result in the protection of its deposits.

\section{Conclusions}

The substrate with the higher compost share had an unfavourable effect on the development of zonal pelargonium. Both OPA and OPB compost variants stimulated the flowering of plants. Actinobacteria and mould reproduced the fastest at the beginning of the experiment, while bacteria reproduced the fastest at the end of the experiment. The highest level of urease activity was observed after the end of the experiment while the highest level of acid phosphatase was observed at the beginning of the cultivation. The type of the used compost was the determinant for the changes in the total counts and microbiological activity. OPA compost was stronger in stimulating mould multiplication and phosphatase and dehydrogenase activity than OPB compost.

The chemical composition of the examined substrates was dependent on the type of wood waste from which compost was made and from its quantitative ratios with peat. The chemical composition of the used substrates modified significantly the nutritional state of the plants as far macro and microelements are concerned. When compared with the control the studied compost caused the increase in the nitrogen, phosphorus, calcium, iron, manganese and zinc contents simultaneously diminishing the contents of potassium and leaving the magnesium and copper contents in pelargonium leaves virtually unchanged.

No significant differences in the average nutrient contents were observed (with the exception of nitrogen) in the leaves of the plants cultivated in both OPA and OPB substrates.

The application of post-consumer wood compost for ornamental plants production in pots with their controlled nutrition can be a valuable alternative to using peat. This can contribute to limiting peat exploitation for horticultural production. Before using the compost variants, it is necessary to perform a chemical analysis and pay special attention to the components that may be critical for the plant's requirements, e.g., $\mathrm{P}$ and $\mathrm{K}$, as well as metallic micronutrients.

Author Contributions: Conceptualization, A.S.-Z.; methodology, A.S.-Z., A.W.-M., T.K., H.W.; softwere, A.S.-Z., A.W.-M., T.K.; validation A.S.-Z., investigation, A.S.-Z., A.W.-M., T.K., K.G.; data curation, A.S.-Z., A.W.-M., T.K.; writing-original draft preparation, A.S.-Z., A.W.-M., T.K., H.W.; writing-review and editing, A.S.-Z., A.W.-M., T.K., H.W.; visualization, A.S.-Z., A.W.-M.; supervision, A.S.-Z., A.W.-M., T.K., H.W.; project administration, A.S.-Z.; funding acquisition, A.S.-Z. All authors have read and agreed to the published version of the manuscript.

Funding: The APC was co-funded within the framework of Ministry of Science and Higher Education program "Regional Initiative Excellence" in years 2019-2022, (No. 005/RID/2018/19)", with financing in the amount of 1,200,000 PLN.

Data Availability Statement: Our study did not report to any data.

Conflicts of Interest: The authors declare no conflict of interest. The funders had no role in the design of the study, in the collection, analyses, or interpretation of data, in the writing of the manuscript, or in the decision to publish the results.

\section{References}

1. Genorowicz, N.; Kowalski, Z. Cascade use post-production waste from wood industry. Energy Policy J. 2020, 23, 87-102. [CrossRef]

2. Gruda, N. Current and future perspective of growing media in Europe. Acta Hortic. 2012, 960, 37-43. [CrossRef] 
3. Alexander, P.D.; Bragg, N.C. Defining sustainable growing media for sustainable UK horticulture. Acta Hortic. 2014, 1034, $219-224$. [CrossRef]

4. Ogbonna, D.N.; Isirimah, N.O.; Princewill, E. Effect of organic waste compost and microbial activity on the growth of maize in the utisolis in Port Harcourt, Nigeria. Afr. J. Biotechnol. 2012, 11, 2546-12554. [CrossRef]

5. Hossain, M.Z.; Von Fragstein, P.; Von Niemsdorff, P.; Hes, J. Effect of Different Organic Wastes on Soil Propertie s and Plant Growth and Yield: A Review. Sci. Agric. Bohem. 2017, 48, 224-237. [CrossRef]

6. Greco, C.; Comparetti, A.; Fascella, G.; Febo, P.; La Placa, G.; Saiano, F.; Mammano, M.M.; Orlando, S.; Ladicina, V.A. Effect of vermicompost, compost and digestate as commercial alternative peat-based substrates on qualitative parameters of Salvia officinalis. Agronomy 2021, 11, 98. [CrossRef]

7. Wraga, K. Effects of media supplemented with compost on vegetative traits and ornamental value of Pentas lanceolata (Forssk.) Deflers. Zesz. Prob. Post. Nauk. Roln. 2008, 525, 477-484.

8. Zawadzińska, A.; Salachna, P. Ivy pelargonium response to media containing sewage sludge and potato pulp. Plant Soil Environ. 2018, 64. [CrossRef]

9. Wróblewska, H.; Kozik, E.; Czajka, M. Effect of compost from wood waste material on the growth and nutritional status of willow Salix alba L. J. Res. Appl. Agric. Eng. 2008, 53, 143-147.

10. Wróblewska, H.; Kozik, E.; Czajka, M. Content of macro- and microcomponents in willow (Salix purpurea L.) grown in substrates with composts of post-use wood waste. Folia For. Pol. Ser. B 2009, 40, $23-30$.

11. Wolna-Maruwka, A.; Schroeter-Zakrzewska, A.; Dach, J. Analysis of the growth and metabolic activity if microorganisms in substrat prepared on the base of sewage sludges and their impact on growth and flowering of garden verbena. Fresenius Environ. Bull. 2012, 21, 325-336. [CrossRef]

12. Mc Mahon, V.; Garg, A.; Aldred, D.; Hobbs, G.; Smith, R.; Tothill, I.E. Composting and bioremediation process evaluation of wood waste materials generated from the construction and demolition industry. Chemosphere 2008, 71, 1617-1628. [CrossRef] [PubMed]

13. Kozik, E.; Wróblewska, H.; Golcz, A.; Wojciechowska, E. Evaluation of the usefulness of compost from post-consumer wood waste for plant growth based on vegetation tests with lettuce (Latuca sativa L.) and basil (Ocimum basilicum L.). Apar. Badaw. Dydakt. 2012, 4, 63-70. (In Polish)

14. Dong, T.; Shang, J.; Chen, J.M.; Liu, J.; Qian, B.; Ma, B.; Morrison, M.J.; Zhang, C.; Liu, Y.; Shi, Y.; et al. Assessment of portable chlorophyll meters for measuring crop leaf chlorophyll concentration. Remote Sens. 2019, 11, 2706. [CrossRef]

15. EN ISO 11133; ISO International Standardisation Organisation. Microbiology of Food, Animal Feed and Water—Preparation, Production, Storage and Performance Testing of Culture Media; ISO: Geneva, Switzerland, 2014.

16. Kańska, Z.; Grabińska-Łoniewska, A.; Łebkowska, M.; Żechowska, E. Laboratory Exercises in Sanitary Biology; Warsaw Technology University: Warsaw, Poland, 2001.

17. Albaum, S.; Masaphy, S. Comparison of rose bengal-chloramphenicol and modified aureomycin-rose bengal-glucose-peptone agar as media for the enumeration of molds and yeasts in water by membrane filtration techniques. J. Microb. Method. 2009, 76, 310-312. [CrossRef] [PubMed]

18. Thalmann, A. Zur Methodik der Bestimmung der Dehydrogenase Aktivität in Boden Mittels Triphenyltetrazoliumchlorid (TTC). Landwirtsch. Forsch. 1968, 21, 249.

19. Tabatabai, M.A.; Bremner, J.M. Use of p-nitrophenyl phosphate for assay of soil phosphatase activity. Soil Biol. Biochem. 1969, 1, 301-307. [CrossRef]

20. Hoffmann, G.; Teicher, K. Ein Kolorimetriches Verfahren zur Berstimmung der Ureaseaktivitat im Boden. Z. Pflanzenernaher. Dung. Bodenkd. 1961, 95, 55-63. [CrossRef]

21. IUNG. Labolatory Test Methods in Chemical and Agricultural Station. Part. III. Examination of Soil, Growing Media under Vegetables and Flowers as well as Indicator parts of Plants for Diagnostic Purposes; IUNG: Puławy, Poland, 1983; pp. 28-81. (In Polish)

22. Ribeiro, H.M.; Vasconcelos, E.; dos Santos, J.Q. Fertilisation of potted geranium with a municipal solid waste compost. Bioresour. Technol. 2000, 73, 247-249. [CrossRef]

23. Wróblewska, H.; Schroeter-Zakrzewska, A.; Głuchowska, K.; Wolna-Maruwka, A.; Kleiber, T. Application of post-consumer wood composts in canna lily (Canna $\mathrm{x}$ generaliis L.H.Bailey) cultivation. Drewno 2014, 57, 5-25. [CrossRef]

24. Brentari, L.; Michelon, N.; Gianquinto, G.; Orsini, F.; Zamboni, F.; Porro, D. Comparative Study of Three Low-Tech Soilless Systems for the Cultivation of Geranium (Pelargonium zonale): A Commercial Quality Assessment. Agronomy 2020, $10,1430$. [CrossRef]

25. Wang, Y.; Dunn, B.L.; Arnall, D.B.; Mao, P. Use of an active canopy sensor and SPAD chlorophyll meter to quantify geranium nitrogen status. Hort. Sci. 2012, 47, 45-50. [CrossRef]

26. Zawadzińska, A.; Salachna, P.; Nowak, J.S.; Kowalczyk, W. Response of interspecific geraniums to waste wood fiber substrates and additional fertilization. Agriculture 2021, 11, 119. [CrossRef]

27. Wróblewska, H.; Schroeter-Zakrzewska, A.; Zakrzewski, P. The use of compost obtained from post-consumer wood waste in the cultivation of zonal pelargonium (Pelargonium zonale) "Andria". Apar. Badaw. Rozw. 2013, 4, 101-108. (In Polish)

28. Niewiadomska, A.; Sulewska, H.; Wolna-Maruwka, A.; Klama, J. Effect of organic fertilization on development of proteolytic bacteria and activity of prteases in the soil for cultivation of maize (Zea Mays L.). Arch. Environ. Protect. 2010, 36, 36-47.

29. Bais, H.; Weir, T.; Perry, L.; Gilroy, S.; Vivanco, J. The role of root exudates in rhizosphere interactions with plants and other organism. Annu. Rev. Plant Biol. 2006, 56, 33-66. [CrossRef] 
30. Vallance, J.; Déniel, F.; Le Floch, G.; Guérin-Dubrana, L.; Blancard, D.; Rey, P. Pathogenic and beneficial microorganisms in soilless cultures. Agron. Sustain. Dev. 2011, 31, 191-203. [CrossRef]

31. Geesey, G.G.; Wigglesworth-Cooksey, B.; Cooksey, K.E. Influence of calcium and other cations on surface adhesion of bacteria and diatoms: A review. Biofouling 2000, 15, 195-205. [CrossRef]

32. De Boer, W.; Folman, L.B.; Summerbell, R.C.; Boddy, L. Living in a fungal world: Impact of fungi on soil bacterial niche development. FEMS Microbiol. Rev. 2005, 29, 795-811. [CrossRef]

33. Howeel, C.R. Mechanisms employed by Trichoderma species in the biological control of plant diseases the history and evolution of current concepts. Plant Dis. 2003, 87, 4-10. [CrossRef]

34. Wolna-Maruwka, A.; Schroeter-Zakrzewska, A.; Borowiak, K. Effect of EM inoculum on the microbiological state of substrate designed for pelargonium (Pelargoniom X hortorum). Nauka Przyr. Technol. 2010, 4, 6. (In Polish)

35. Niewiadomska, A.; Kleiber, T.; Komosa, A. Optimization of Lawn Fertilization with Nitrogen Part III. Dynamics of soil microbiological composition and enzymatic activity of dehydrogenases. Ecolgical Chem. Eng. A. 2010, 17, 1597-1606.

36. Hartman, W.H.; Richardson, C.J. Differential nutrient limitation of soil microbial biomass and metabolic quotients $\left(\mathrm{qCO}_{2}\right)$ : Is there a biological stoichiometry of soil microbes? PLoS ONE 2013, 8, 57127. [CrossRef]

37. Dijber, R.A.; Doran, J.W.; Parkhurst, A.M.; Lyon, D.J. Changes in soil microbial community structure with tillage under long-term wheat-fallow management. Soil Biol. Biochem. 2000, 22, 1419-1430. [CrossRef]

38. Koper, J.; Siwik-Ziomek, A. Seqvential activity of monoculture and croprotation on the soil amylase and dehydrogenase activity against the soil physico-chemical parameters. Zesz. Probl. Postęp. Nauk. Roln. 2003, 493, 637-643. (In Polish)

39. Wyszkowska, J.; Wyszkowski, M. Activity of dehydrogenases, urease and phosfatases in soil polluted with petroleum. J. Toxicol. Environ. Health A 2010, 73, 1202-1210. [CrossRef] [PubMed]

40. Singh, G.; Bhattacharyya, R.; Das, T.K.; Sharma, A.R.; Ghosh, A.; Das, S.; Jha, P. Crop rotation and residue management effects on soil enzyme activities, glomalin and aggregate stability under zero tillage in the Indo-Gangetic Plains. Soil Till. Res. 2018, 184, 291-300. [CrossRef]

41. Brzezińska, M.; Włodarczyk, T. Enzymes of intercellular redox transformations (oxidoreductases). Acta Agrophys. 2005, 3, 11-16.

42. Król, M.J.; Perzyński, A.; Leśniak, A.; Smagasz, J. Biological activity of medium- dust mada fertilized with straw under the cultivation of winter wheat in monoculture. Acta Agr. Silv. 2006, 49, 267-280. (In Polish)

43. Żebrowska, E.; Ciereszko, I. Acid phosphatases role in plant cells phosphate homeostasis. Adv. Cell Biol. $2009,36,583-599$.

44. Dąbek-Szreniawska, M.; Zimon, A.; Wyczółkowski, A. Soil enzimes activity of amonification proces in the soil with the addition of organic nitrogen. Acta Agrophysica 2006, 8, 23-33. (In Polish)

45. Kozik, E.; Wróblewska, H.; Bosiacki, M.; Wojciechowska, E. The use of wood waste compost in the cultivation of selected species of ornamental plants. Apar. Badaw. Dydakt. 2010, 4, 75-81. (In Polish)

46. Kleiber, T.; Schroeter-Zakrzewska, A. Chlomequat and metconazole in the growing of garden pelargonium (Pelargonium hortorum L.H. Bailey) "Aida". Part. II. Macroelements status of plants. Nauka Przyr. Technol. 2010, 4, 4. (In Polish)

47. Digat, B.; Lemaire, F. Nitrogen form and susceptibility of Pelargonium $\times$ hortorum to xanthomonas. Acta Hortic. 1993, 342, 25-35. [CrossRef]

48. Lemaire, F.; Dartigues, A. Influence of $\mathrm{CaCO}_{3}$ added to the substrate on the nitrogen nutrition of Pelargonium hortorum mother plants. Acta Hortic. 1983, 150, 203-217. [CrossRef]

49. Kreij, C.; Sonneveld, C.; Warmenhoven, M.G.; Straver, N. Normen voor gehalten aan voedingselementen van groenten en bloemen onder glas. Ser. Voedingsplossingen Glastuinbouv. 1990, 15, 23.

50. Laboratorium Orange-Citation from Nowosielski, O. Methods of Determining Fertilization Needs; PWRiL: Warszawa, Poland, 1974. (In Polish)

51. Lis-Krzyścin, A. N fertilization and nutrient status of geranium plant (Pelargonium x hortorum). Acta Agrophysica 2006, 7, 651-661. (In Polish)

52. Kleiber, T.; Schroeter-Zakrzewska, A. Chlomequat and metconazole in the growing of garden pelargonium (Pelargonium hortorum L.H. Bailey) "Aida". Part III. Metallic microelements and sodium status of plants. Nauka Przyr. Technol. 2010, 4, 45. (In Polish)

53. Wróblewska, H.; Czajka, M.; Tymek, A. Characteristic of compost obtained from post-consumer wood materials. In Effective Waste Management; Futura i PZITS: Poznań, Poland, 2007. (In Polish) 